
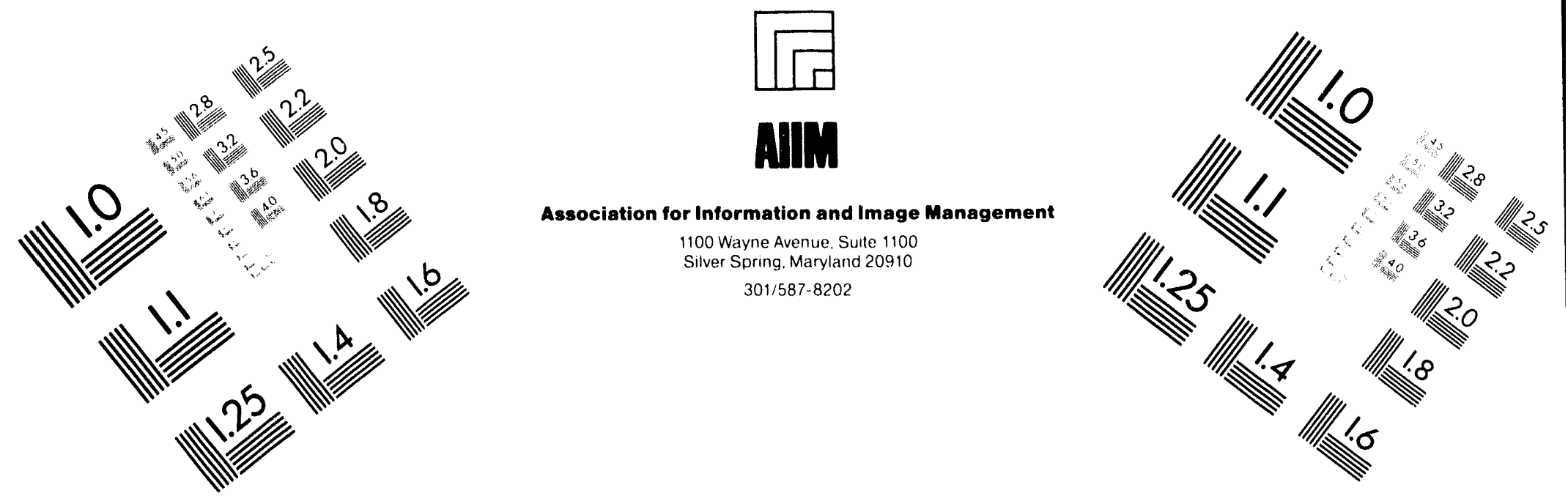

\title{
Centimeter
}

| Inches
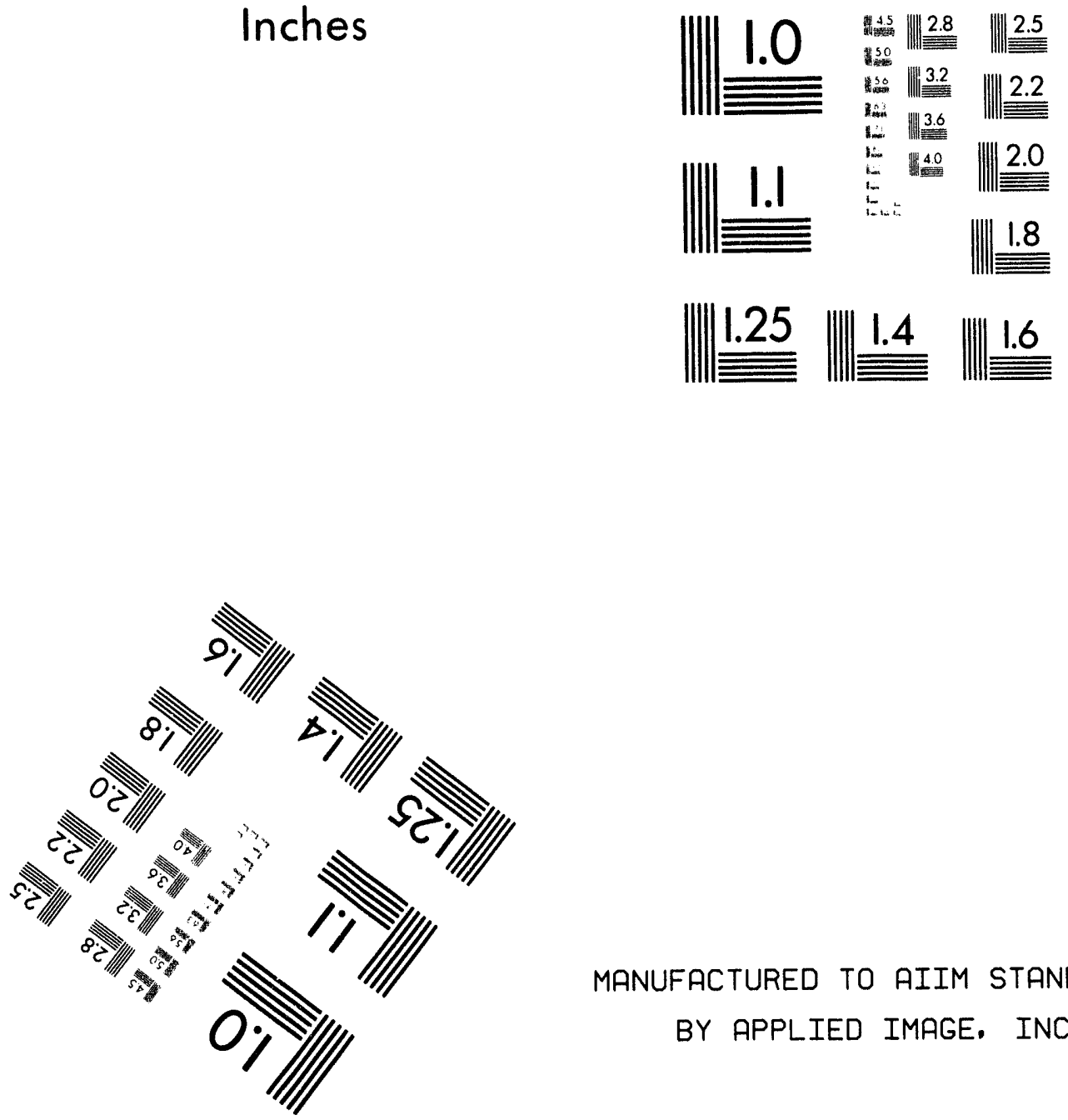

MANUFACTURED TO AIIM STANDARDS

BY APPLIED IMAGE. INC.

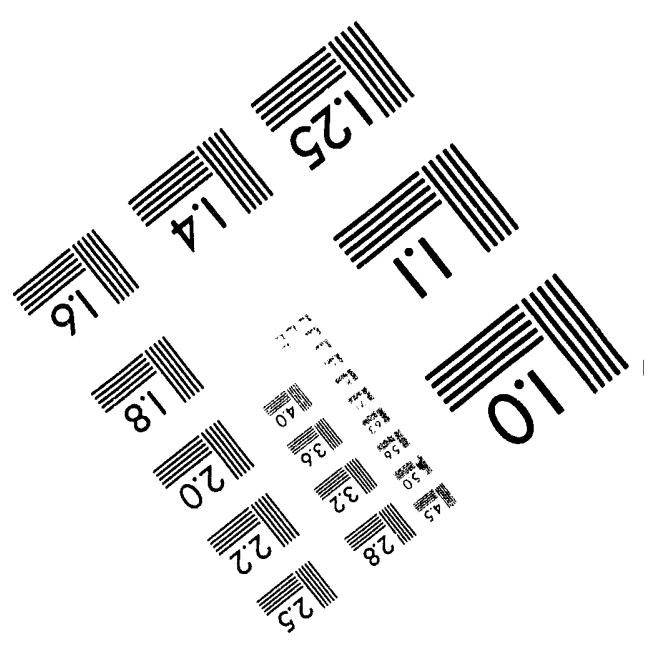



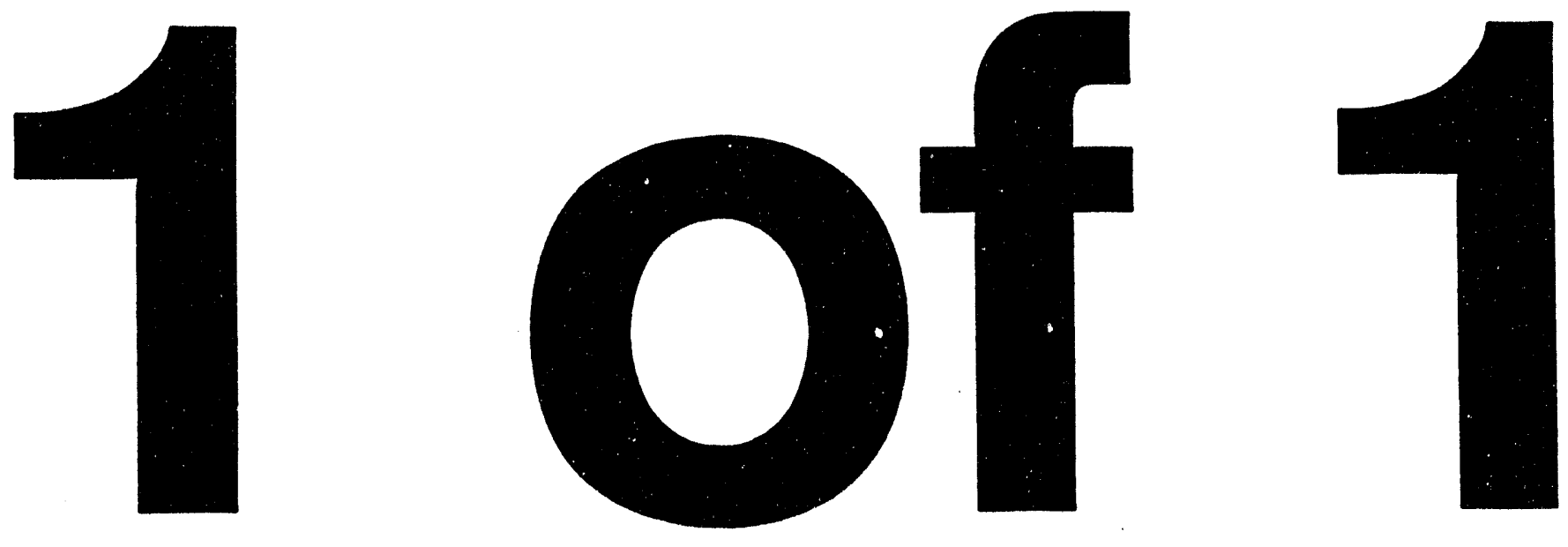
DOE/NV/10412-9

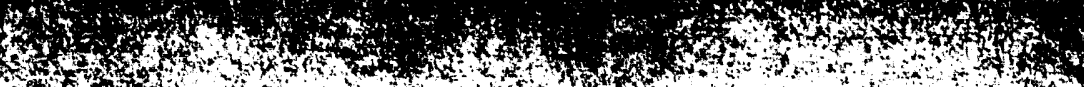
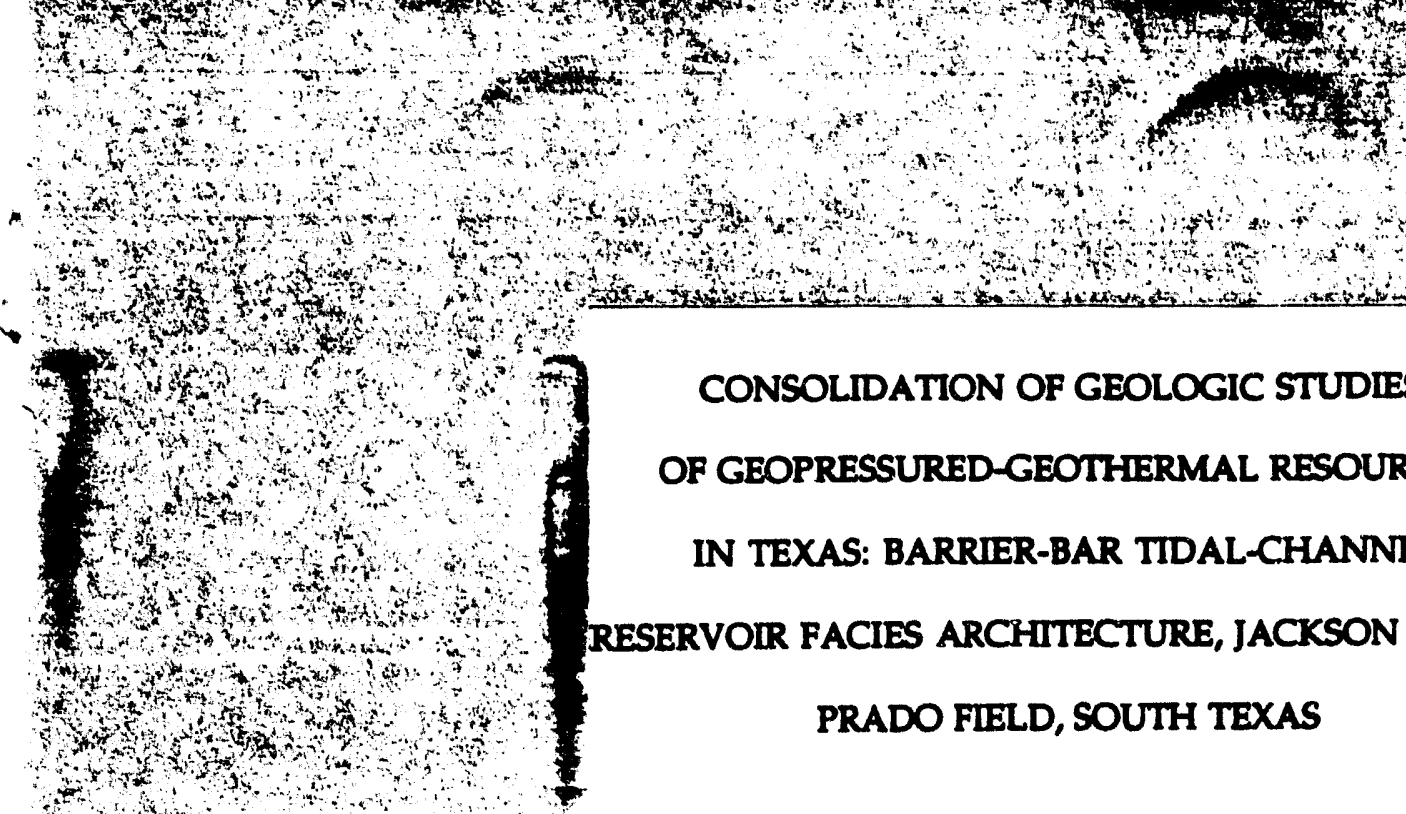

ond ond

$4 x+40$

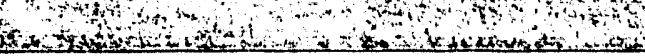

CONSOLIDATION OF GEOLOGIC STUDIES

OF GEOPRESSURED-GEOTHERMAL RESOURCES

IN TEXAS: BARRIER-BAR TIDAL-CHANNEL

RESERVOIR FACIES ARCHITECTURE, JACKSON GROUP,

PRADO FIELD, SOUTH TEXAS

Final Report

BUREAU OF ECONOMIC GEOLOGY

THE UNIVERSITY OF TEXAS

AT AUSTIN

W. L. FISHER, DIRECTOR

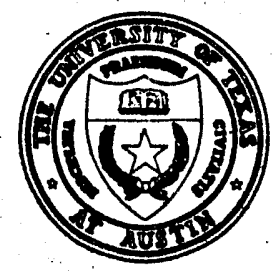

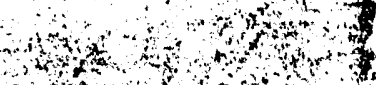
thothos

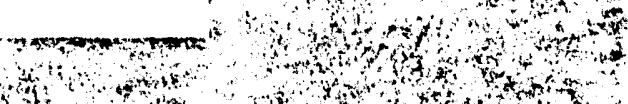
ath of the

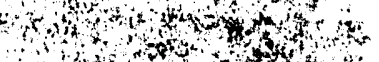
. to th 


\section{CONSOLIDATION OF GEOLOGIC STUDIES \\ OF GEOPRESSURED-GEOTHERMAL RESOURCES \\ IN TEXAS: BARRIER-BAR TIDAL-CHANNEL \\ RESERVOIR FACIES ARCHITECTURE, JACKSON GROUP, \\ PRADO FIELD, SOUTH TEXAS}

Final Report

by Steven J. Seni and Suk Joo Choh

Prepared for the U.S. Department of Energy

Advanced Technologies Division

under Cooperative Agreement No. DE-FC07-85NV10412

Bureau of Economic Geology

W. L. Fisher, Director

The University of Texas at Austin

Austin, Texas 78713-7508

September 1993

Whact 


\section{CONTENTS}

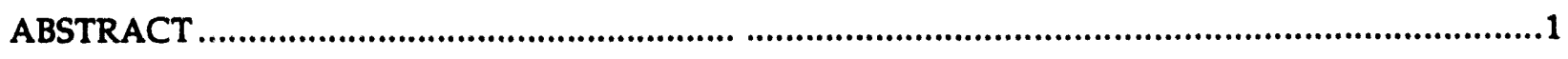

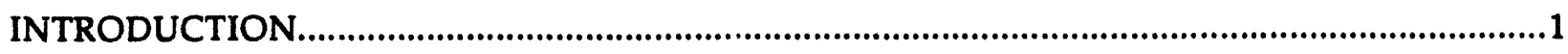

PRADO FIELD

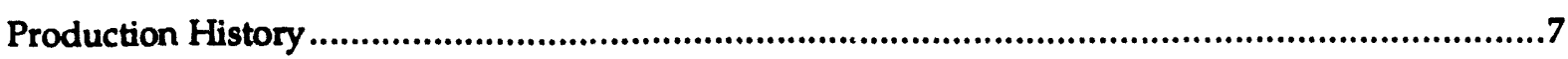

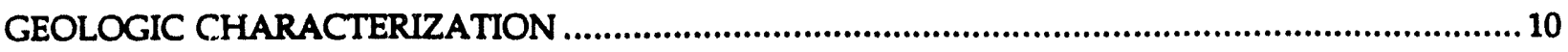

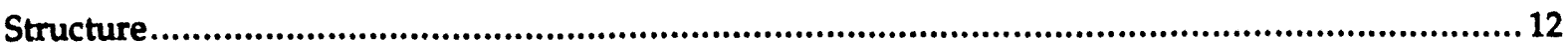

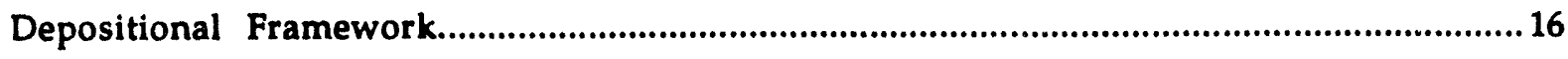

Sand-Body Architecture and Depositional Facies ........................................................20

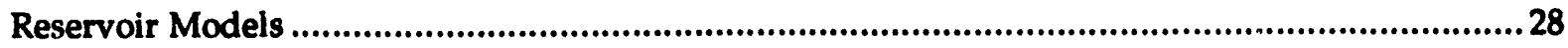

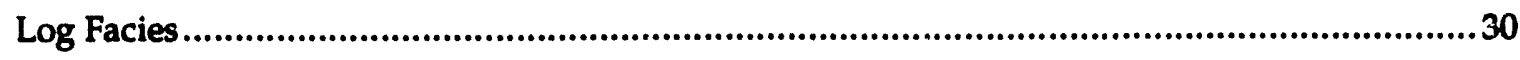

Unsegmented Barrier-Bar Reservoir Model .........................................................................35

Tidal Channel-Inlet Fill Reservoir Model .........................................................................40

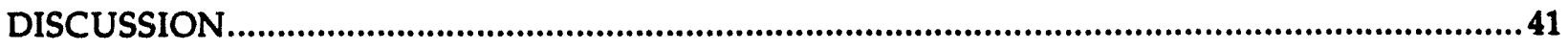

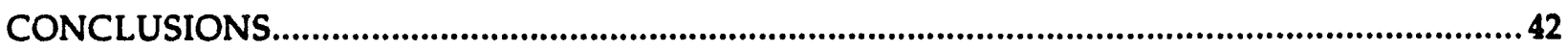

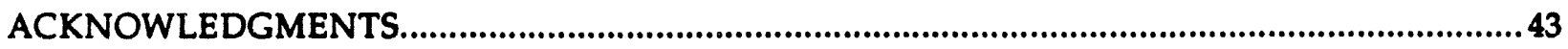

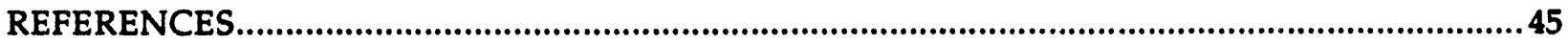

Figures

1. Outline of Jackson-Yegua barrier/strandplain play, South Texas...........................................4

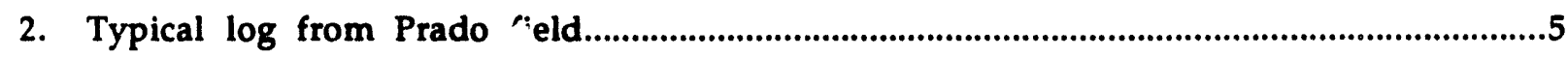

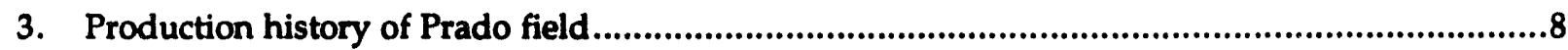

4. Map showing initial potential reported for wells in Prado field.........................................9

5. Well control and general structural configuration around Prado field .................................... 11

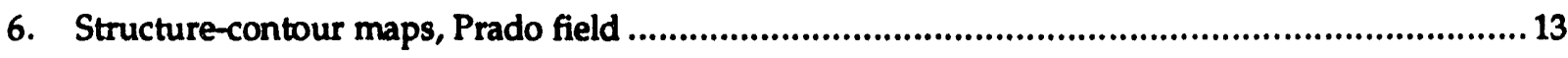


7. Stratigraphic dip-oriented cross section, Prado field area...................................................14

8. Structure-contour map of top Middle Loma Novia II sandstone ............................................15

9. Structural cross section showing structural crest over sand-rich Middle Loma Novia interval ... 17

10. Net-sandstone map of lower Jackson Group and distribution of major Jackson oil reservoirs........ 19

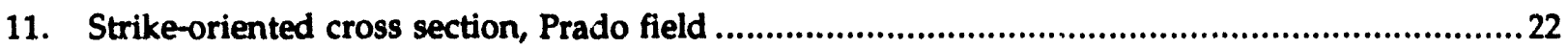

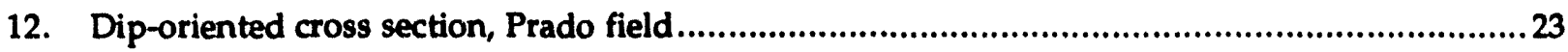

13. Percentage-sandstone maps, Prado field..................................................................................24

14. Map of axis of maximum sandstone accumulation and updip and downdip lines

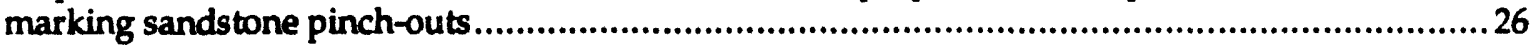

15. Component depositional facies of barrier-bar sand body .................................................29

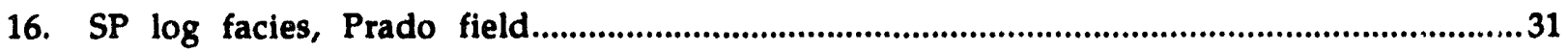

17. Detailed electric log and lithologic description of reservoir interval..................................33

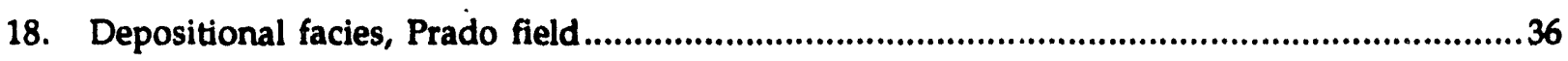

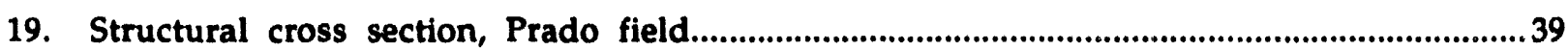

\section{Table}

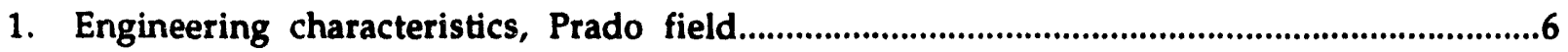

\section{Appendices}

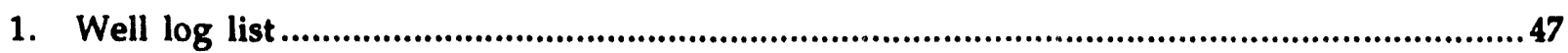

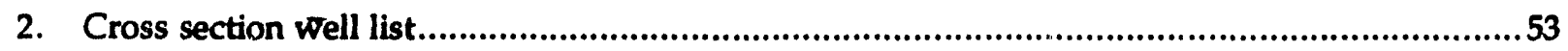




\section{ABSTRACT}

Sandstone reservoirs in the Jackson barrier/strandplain play are characterized by low recovery efficiencies and thus contain a large hydrocarbon resource target potentially amenable to advanced recovery techniques. Prado field, Jim Hogg County, South Texas, has produced over 23 million bbl of oil and over 32 million mcf gas from combination structural-stratigraphic traps in the Eocene lower Jackson Group. Hydrocarbon entrapment at Prado field is a result of anticlinal nosing by differential compaction and updip pinch-out of barrier bar sandstone. Relative base-level lowering resulted in forced regression that established lower Jackson shoreline sandstones in a relatively distal location in central Jim Hogg County. Reservoir sand bodies at Prado field comprise complex assemblages of barrier-bar, tidal-inlet fill, back-barrier bar, and shoreface environments. Subsequent progradation built the barrier-bar system seaward 1 to $2 \mathrm{mi}$. Within the barrier-bar system, favorable targets for hydrocarbon reexploration are concentrated in tidal-inlet facies because they possess the greatest degree of depositional heterogeneity.

\section{INTRODUCTION}

Barrier/strandplain depositional systems host important hydrocarbon reservoirs in Tertiary strata of the Texas Gulf Coast Plain (Galloway and others, 1983). Major hydrocarbon plays are associated with the following barrier/strandplain depositional systems: Miocene (Galloway and others, 1986), Oligocene Frio Formation (Galloway and others, 1982; Galloway and Cheng, 1985), and Eocene Jackson Group (Fisher and others, 1970). Fields in the Frio Formation Greta-Carancahua barrier/strandplain system have undergone modern, detailed reservoir studies (Galloway and Cheng, 1985; Tyler and Ambrose, 1985), in part reflecting that system's tremendous hydrocarbon endowment. Galloway and others (1983) estimate that reservoirs greater than 10 million bbl in the Frio barrier/strandplain play contain 4.2 billion bbl of oil in place. Recovery efficiency for the large reservoirs in Frio barrier/strandplain plays is a : latively high 54 percent (weighted average of Frio barrier/strandplain plays; Galloway and others, 1983). Large reservoirs in the Eocene Jackson Group South Texas barrier/strandplain play contain an estimated 
1.2 billion bbl of oil in place (Galloway and others, 1983) and have produced 431 million bbl of oil (through 1/1/92). However, Jackson Group reservoirs have an average recovery efficiency of only 38 percent (Galloway and others, 1983).

Barrier/strandplain reservoirs of the Jackson Group of South Texas are characterized by stratigraphic entrapment of oil at shallow burial depth. Recovery efficiencies for the play are relatively low despite high porosity and permeability typical of barrier/strandplain deposits. The low recovery efficiencies are presumed to result from low API gravities, weak solution drive, and reservoir heterogeneities. Tyler and Ambrose (1985) cite the preferential stratigraphic entrapment of oil in thin back-barrier reservoirs as contributing to poor recovery efficiency from the Jackson Group. Secondary recovery waterflood techniques typically are used to assist the weak solution drive. Many reservoirs have undergone tertiary recovery techniques including steam stimulation, fire floods, and miscible floods. Another advanced recovery technique-geothermal water flood - has been proposed as a potential method for improving recovery efficiency (Seni and Walter, in press). The low recovery efficiency of Jackson Group barrier/strandplain reservoirs indicates that a substantial resource target for enhanced oil recovery exists in known reservoirs at relatively shallow depth. Thus, Jackson Group reservoirs are appropriate for detailed reservoir studies because of the large remaining oil resource target and because they have not received the detailed reservoir characterization that has been afforded the Frio Formation.

Prado field in Jim Hogg County was selected for detailed reservoir characterization as a typical example of a large multireservoir field in the Jackson Group barrier/strandplain system of South Texas. Both secondary and advanced tertiary recovery operations are predicated on a thorough understanding of reservoir architecture. Evaluation of the potential for field reexploration and for increasing oil recovery in Texas requires detailed field examples of selected reservoirs. Prado field is suited for such an appraisal owing to the abundance of subsurface well data and the commitment of the current field operator to field reexploration.

The purpose of this report is (1) to describe and analyze the sand-body architecture, depositional facies variations, and structure of Prado field, (2) to determine controls on distribution of hydrocarbons pertinent to reexploration for bypassed hydrocarbons, (3) to describe reservoir models at Prado field, and 
(4) to develop new data affecting the suitability of Jackson oil fields as possible candidates for thermally enhanced recovery of medium to heavy oil.

\section{PRADO FIELD}

Prado field in Jim Hogg County, South Texas, produces oil and gas from the downdip margin of Jackson Group barrier/strandplain play (fig. 1). Most Jackson fields were discovered in the 1920's and 1930's. Prado field was discovered in 1956, late in the exploration history of the Jackson Group (West, 1963). Prado has produced over 23 million bbl of oil and is currently undergoing reexploration following an extended period of steeply declining production. Primary targets are bypassed hydrocarbons in small untapped compartments isolated by stratigraphic heterogeneities. Reservoir sandstones in Prado field produce hydrocarbons from combination stratigraphic/structural traps in narrow, strike-elongate sandstones that are encased in shale. Sand bodies extend subregionally and are locally designated from top to bottom as the Upper Government Wells, Middle Government Wells, Lower Government Wells, Upper Loma Novia, Middle Loma Novia, and Prado (fig. 2, Prado S. K. East No. 54). Stratigraphic entrapment is a result of updip pinch-out of barrier-bar, back-barrier, and tidal-channel sandstones. The more subtle structural component is a result of differential compaction. Although the initial field discovery was in the Prado sand, the Middle Loma Novia is the primary producer and is divided into a series of discrete reservoirs (LN I, LN II, LN III) that have uncertain reservoir compartmentalization and gas/oil/water contacts.

Geologic and engineering characteristics of Prado field are listed in table 1. Approximately 68.9 million bbl of oil is estimated to have originally been in place in Middle Loma Novia reservoirs. Cumulative oil production of $\mathbf{2 3}$ million bbl yields a recovery efficiency of 34 percent. Reservoir production energy is derived predominantly from solution gas drive and gas cap expansion. Relatively rapid downdip and updip pinch-out of reservoir sandstones limits water drive berause of the small size of the available aquifer. Average porosity from the primary Middle Loma Novia reservoirs is 32 percent and average permeability is $901 \mathrm{md}$. The Middle Loma Novia and Prado reservoirs are complex 


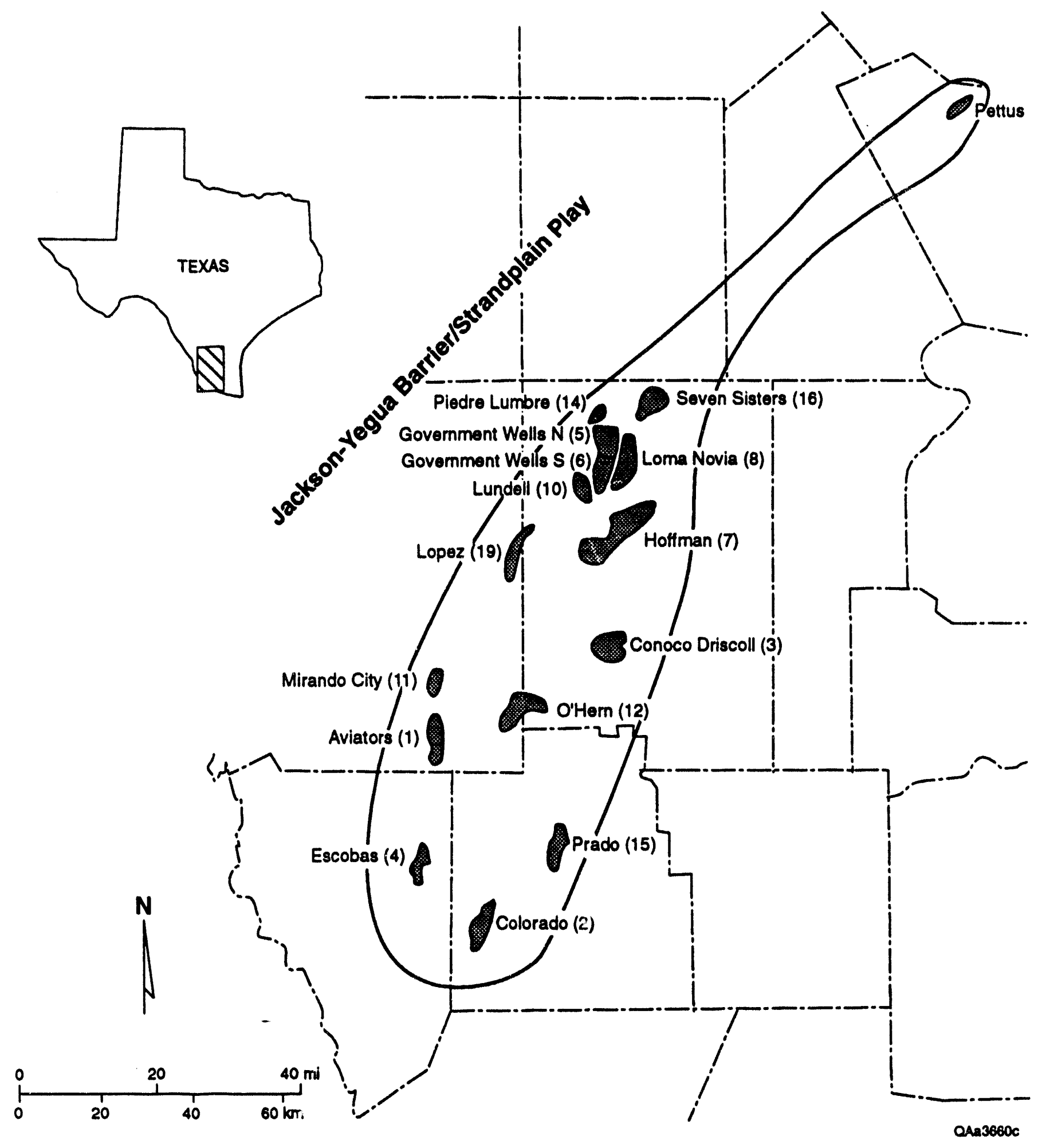

Figure 1. Outline of Jackson-Yegua barrier/strandplain play, South Texas. Only fields with reservoirs that have cumulative production greater than 10 million bbl are shown. Numbers next to field names refer to specific fields shown in figure 10. Modified from Galloway and others (1983). 


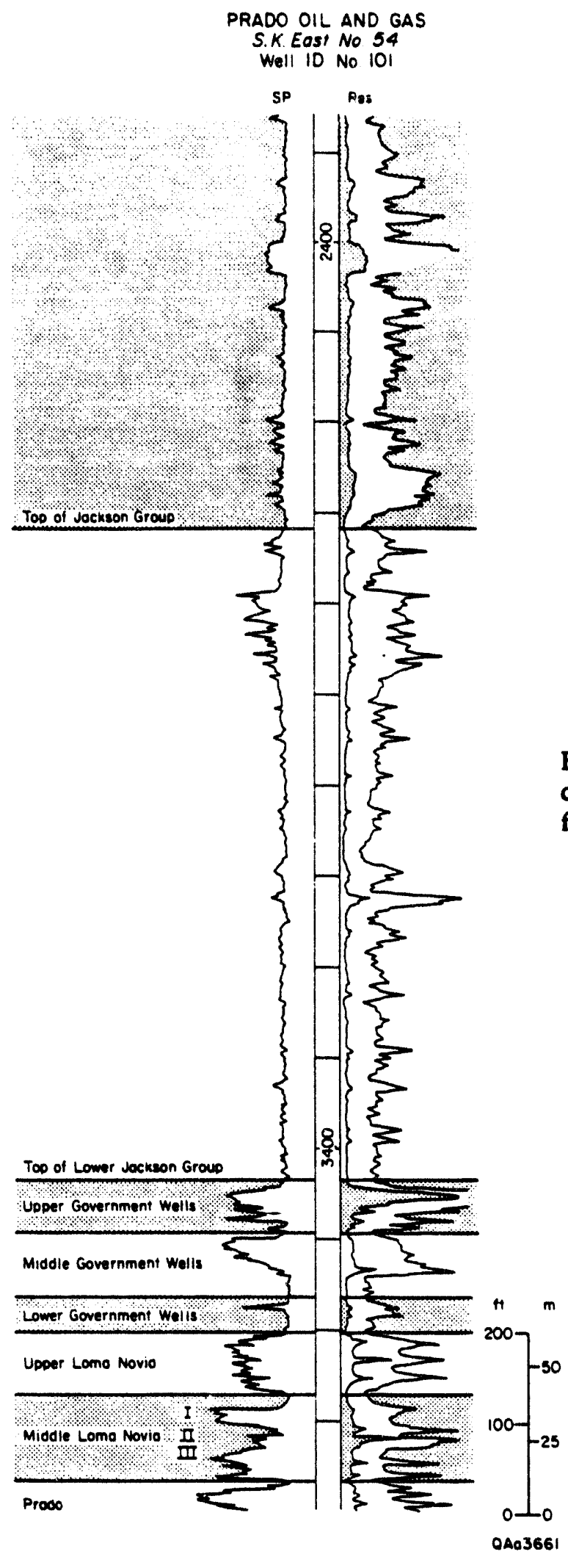

Figure 2. Typical log from Prado field showing electric log characteristics and field-specific nomenclature of upwardfining sand bodies. 
Table 1. Engineering characteristics, Prado field.

\begin{tabular}{|c|c|c|}
\hline PRADO FIELD & Main Gas Reservoir & Main Oil Reservoir \\
\hline Reservoirs & Upper Government Wells & Middle Loma Novia \\
\hline County & Jim Hogg & Jim Hogg \\
\hline Discovery & July 1956 & July 1956 \\
\hline Hydrocarbon type & gas & oil \\
\hline Depth subsea & $2,800 \mathrm{ft}$ & $3,050 \mathrm{ft}$ \\
\hline Porosity (ave.) & & $31.70 \%$ \\
\hline Permeability (md ave. and range) & & $906 \mathrm{md}(55-5946)$ \\
\hline Area & 3,275 acres & 2,076 acres \\
\hline Net pay & $20 \mathrm{ft}$ & $28.5 \mathrm{ft}$ \\
\hline Reservoir pressure (initial) & & 1,407 psig \\
\hline Reservoir pressure (current) & & 1,082 psig \\
\hline Estimated original gas/oil in place & 35 bcf & $68.3 \mathrm{mmbbl}$ \\
\hline Water saturation & & $26 \%$ \\
\hline Bubble point & & 1,407 psi \\
\hline Formation factor & & 1.2045 \\
\hline Temperature & & $109^{\circ} \mathrm{F}$ \\
\hline Oil gravity & & 39.6 \\
\hline Transmissibility & & $1,667 \mathrm{md}-\mathrm{ft} / \mathrm{cp}$ \\
\hline Target oil & $650 \mathrm{mmcf} / \mathrm{acre}-\mathrm{ft}$ & 384 stock tank bbl/acre-ft \\
\hline Cumulative production & $25,277,059$ mcf & $23,474,000 \mathrm{bbl}$ \\
\hline Production in 1991 & 0 mcf & $2,200 \mathrm{bbl}$ \\
\hline Well spacing & 200 acres/well & 13 acres/well \\
\hline Drive & gas cap, pressure depletion & gas cap, solution gas, weak water drive \\
\hline Stage of depletion & tertiary & secondary \\
\hline Secondary production & none & waterflood \\
\hline
\end{tabular}


assemblages of upward-coarsening and upward-fining sand bodies and interbedded mudstone. The Governnient Wells (Upper and Lower) and Upper Loma Novia reservoirs are much more homogeneous, upward-coarsening sand bodies. Detailed characterization of the reservoir sandstones follows in the section "Sand-Body Architecture and Depositional Systems."

\section{Production History}

According to Railroad Commission of Texas (RRC) annual reports, 16 reservoirs have produced oil or gas in Prado field. The Upper Government Wells is the principal gas reservoir, whereas the Middle Loma Novia is the principal oil reservoir. The RRC merged the nine oil reservoirs into a single combined reser:oir for reporting purposes in 1967 (fig. 3). Gas production peaked in 1962 at 7.183 million mcf/yr ant has since declined steeply. Prado oil production peaked in 1967 at 2.66 million bbl/yr. Oil production has declined steeply since 1967, the steepest decline occurring after 1983. Current oil production in 1991 increased to $2,200 \mathrm{bbl} / \mathrm{yr}$ from $294 \mathrm{bbl}$ in 1990 . The decline in gas production preceded that of oil production, but gas production recovered slightly and held steady at about $31,750 \mathrm{mcf} / \mathrm{yr}$ from 1978 to 1985 as gas was produced from the gas cap of the Middle Loma Novia reservoirs. Post-1985 gas production has plummeted, with no gas production reported from 1988 to 1991.

The initial potential of most wells completed in Loma Novia reservoirs ranged from 60 to $120 \mathrm{bbl} / \mathrm{d}$ (fig. 4), and most wells initially produced 80 to $100 \mathrm{bbl} / \mathrm{d}$. Wells with low initial potential (less than $80 \mathrm{bbl} / \mathrm{d}$ ) are concentrated on the updip and downdip margins of the field. Wells in the center of the field with high initial potential (greater than $100 \mathrm{bbl} / \mathrm{d}$ ) are dip aligned.

In 1961, the RRG granted the field operator authority (Special Order No. 4-45,735) to inject gas and water into the re:ervoir in order to maintain reservoir pressure. Initially, gas produced from the Upper Government Wells reservoirs was reinjected into the gas cap of Middle Loma Novia reservoirs. After depletion of the Upper Government Wells gas reservoir, a program of water injection for pressure maintenance was begun in 1967. Initially, producing wells on the downdip side of the field that watered out were converted to injection wells. Later, producing wells from the center of the field were converted to injection wells. The reservoir did not respond favorably to the water injection program, and production 
(घ)

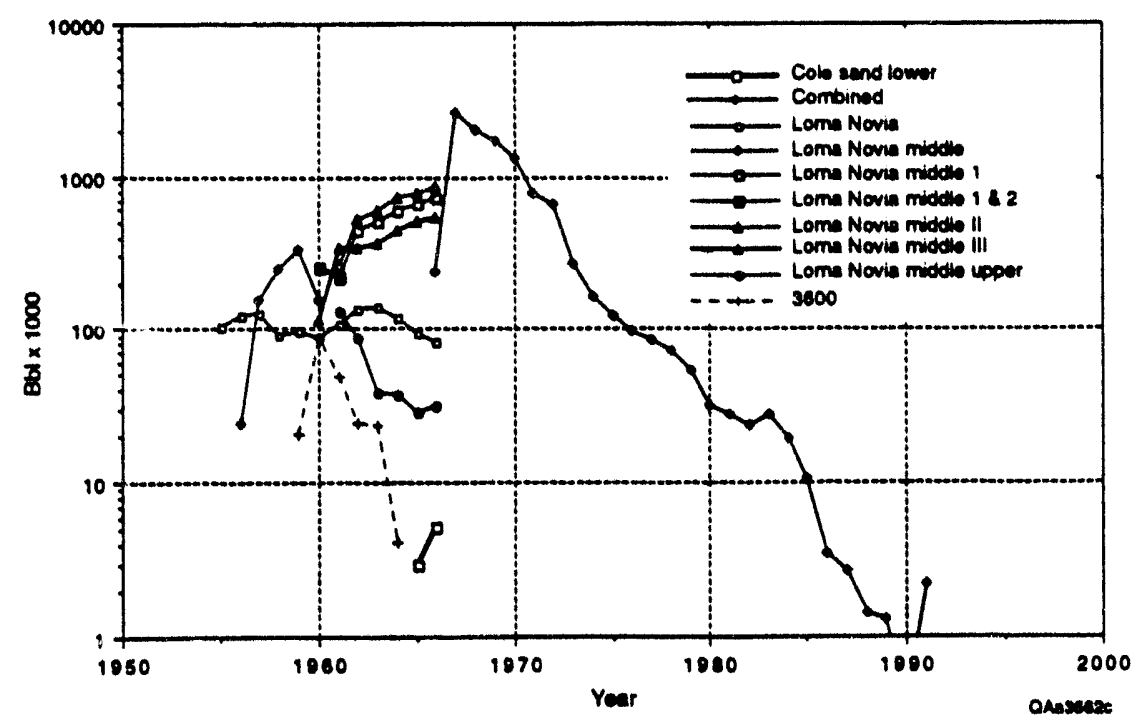

(b)

(c)
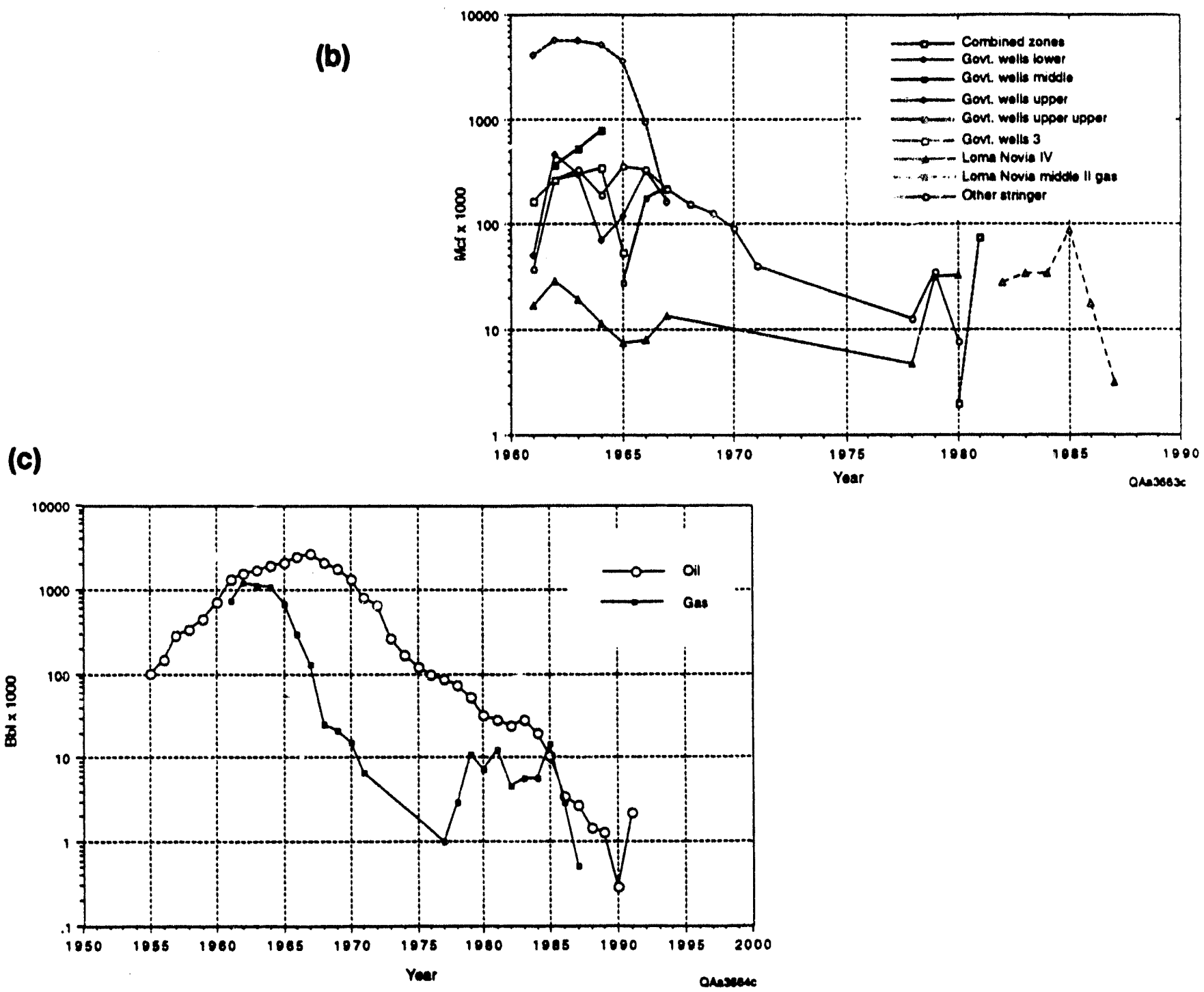

Figure 3. Production history of Prado field from Railroad Commission of Texas annual reports. Figure 3a and 3b show production for individual oil and gas reservoirs, respectively. Figure 3 cshows field wide cumulative oil and gas production. 


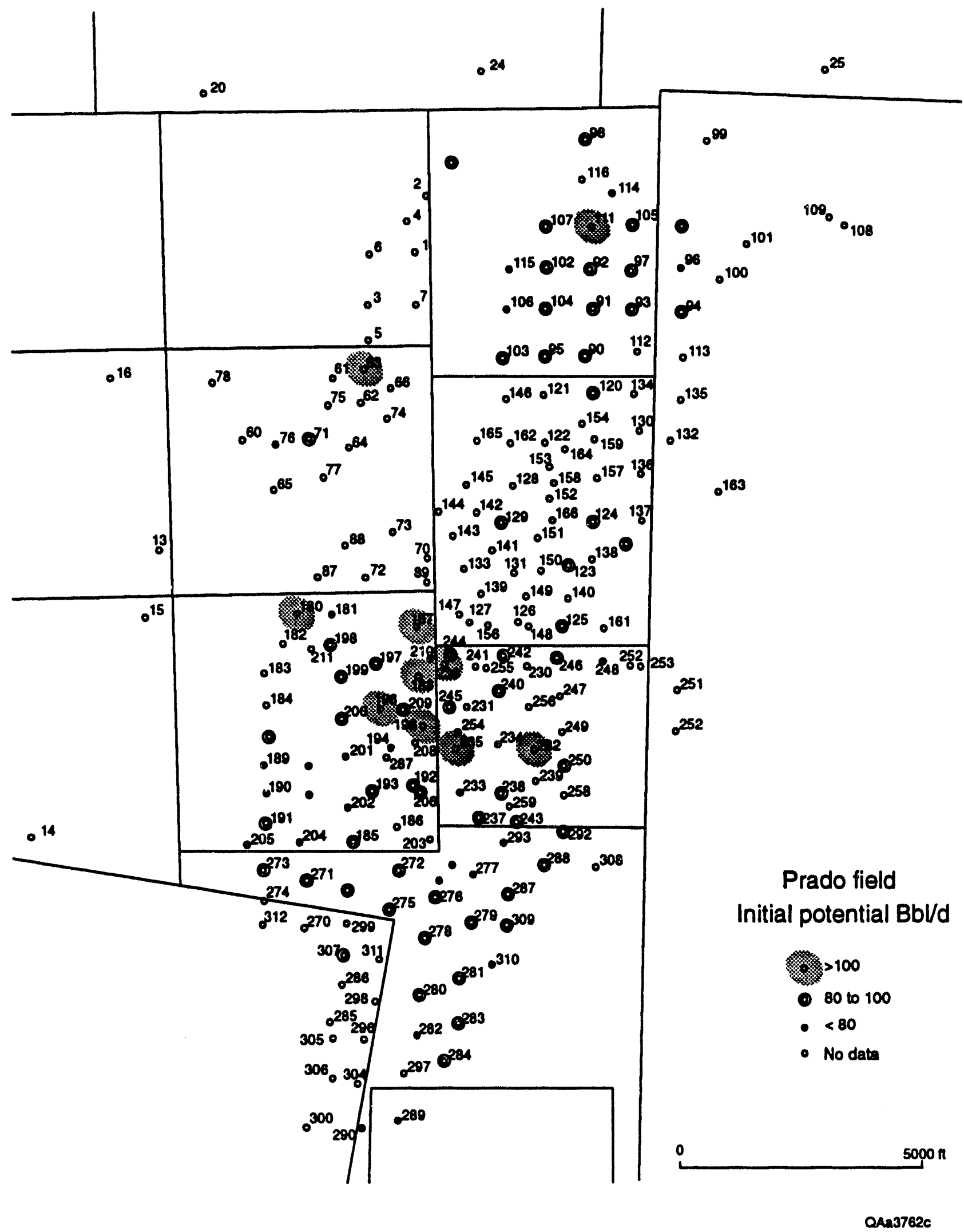

Figure 4. Map showing initial potential reported for wells in Prado field. 
declined at an increasing rate after 1970 . The volume of water that was injected is unknown. Unfortunately, more detailed production records are unavailable. Production is reported to the RRC by lease but not by well. Because all the wells in Prado field are on a single lease (no. 06673 East S. K.), further subdivision of production records was impossible. Ownership of the field has changed hands repeatedly, and production records from the original operators are unavailable, even to the current operator (Chase Petroleum and PI Energy, Inc.).

\section{GEOLOGIC CHARACTERIZATIONं}

Abundant subsurface well log data are available for detailed geologic characterization of Prado field. Data from more than 300 well logs and scout cards are plotted in the immediate vicinity of Prado field. Subregional well data from the surrounding five-county area of Duval, Jim Hogg, Webb, Starr, and Zapata Counties are also available (Seni and Walter, in press). Pertinent geologic data for computerized mapping of structure, thickness, net sandstone, and percentage sandstone are organized in a geographic information system (GIS). Well control is illustrated on a structure-contour map on the top of the Jackson Group (fig. 5). Appendix 1 lists well index numbers and well names. Appendix 2 lists well names shown on cross sections.

Well logs are the primary means of subsurface analysis of the structure and depositional systems of Prado field. Local cores were unavailable, but log descriptions of well cuttings helped confirm the presence of lignite. Subsurface well control is dense. Average well spacing is 20 acres/well. Most wells were 1 inch to $100 \mathrm{ft} \mathrm{SP-resistivity} \mathrm{logs.} \mathrm{Two-inch} \mathrm{and} \mathrm{5-inch} \mathrm{SP-resistivity} \mathrm{logs} \mathrm{were} \mathrm{also} \mathrm{used} \mathrm{where}$ available. Data interpreted from individual logs were incorporated into a GIS. Such data include tops, isopachs, net sandstone, and percent sandstone from the following sequences-Jackson (top only), Upper Government Wells, Middle Government Wells, Lower Government Wells, Upper Loma Novia, middle Novia, Prado, and Pettus. Data from ARCInfo GIS and contouring packages from Radian CPS were used to generate a variety of maps depicting the structure, depositional facies variations, and upward-fining architecture. 


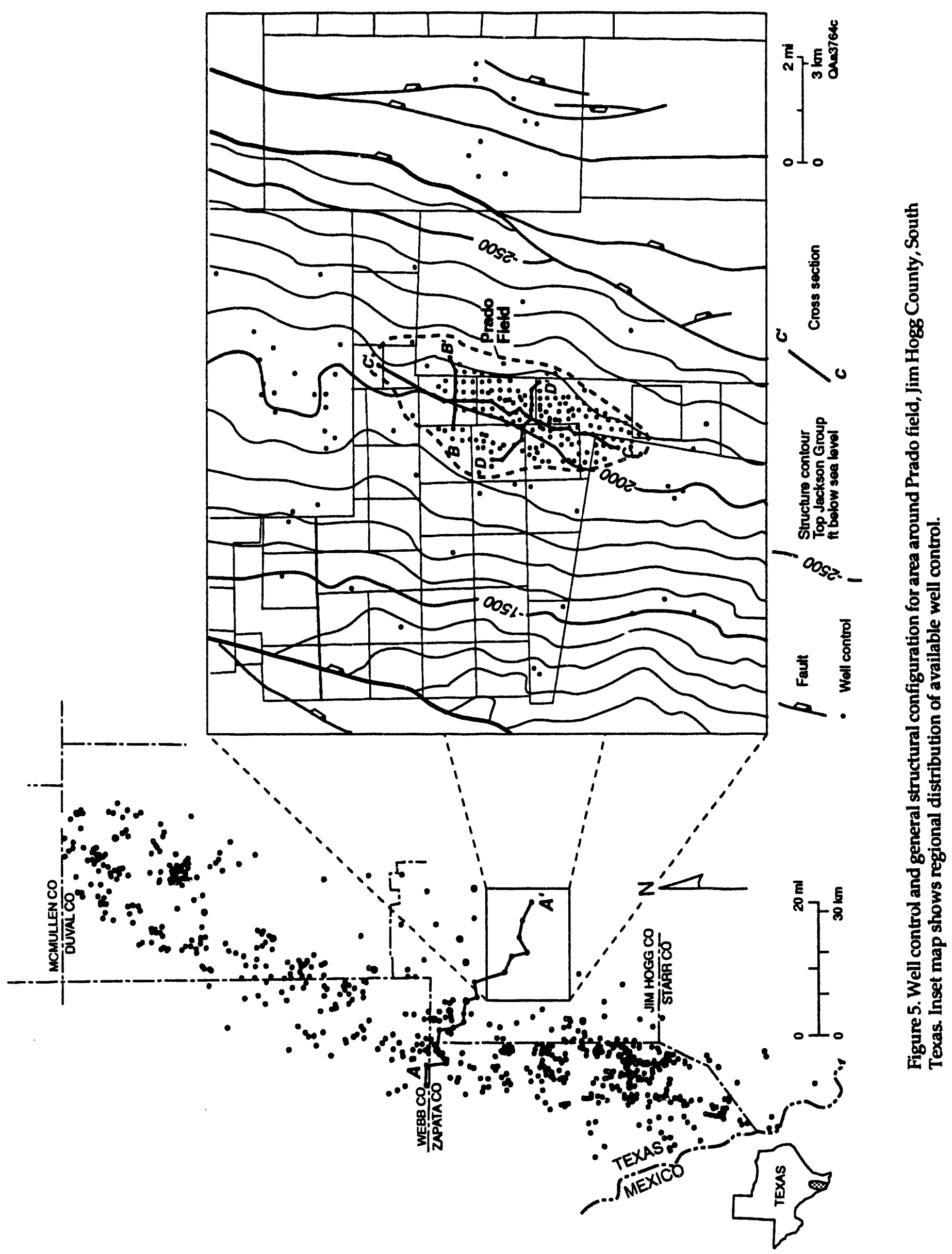




\section{Structure}

Although the structural aspects of Prado field are less complex than the stratigraphic depositional features, pronounced variations in the thickness and percentage sandstone of the Lower Jackson are inferred to have caused subtle structural drape over the area of the field and thus contributed to localization of the field. The Prado field area lies between the Wilcox and Frio growth fault zones in South Texas (fig. 5). In the immediate area of the field, no large faults or major structural discontinuities are evident on the scale of regional structure maps. The top of the Jackson dips east-southeast at the rate of $200 \mathrm{ft} / \mathrm{mi}$. Because the trend of the updip pinch-out of sandstone coincides with the structural dip, an additional lateral barrier to migration is needed to close the tra', especially to the north. At Prado field, the northern closure results where the sandstone pinch-out line crosses structural contours, that is northern closure occurs where the sandstone pinch-out line swings east and plunges down structure.

Within Prado field, detailed structural mapping of individual horizons reveals the pmgressive development of a structural high across the field that increases in amplitude from oldest to youngest units as a result of compaction over the sand-rich core of the field (fig. 6). The top Prado is the oldest sandstone mapped in the field area because of the lack of deeper control on the Yegua Formation. The structure-contour map illustrates the relatively planar surface of the top of Prado sandstone and the dip to the southeast of 75 to $100 \mathrm{ft} / \mathrm{mi}$. The structure of younger sand bodies in the Prado field illustrates the progressive deveiopment of a structural nose with a relief of up to 25 to $30 \mathrm{ft}$. This structural component of Prado field is also seen on a stratigraphic dip section across the field (fig. 7). Again the monoclinal basinward dip of horizons is interrupted across Prado field where lower Jackson sand bodies have accumulated a relatively thick, sandy interval, presumably as a result of stabilization of the paleoshore line. The tops of youngest sandstones are folded in a gentle anticline that achieves its greatest relief where the sandstone percentage is the thickest.

Minor intrafield structural saddles along the updip margin of Prado field supports the interpretation that changes in sandstone thickness and percentage also affect intrafield structure. Figure 8 is an operator-supplied structiure-contour map (RRC Docket Number 4-55,323) of the Middle Loma 


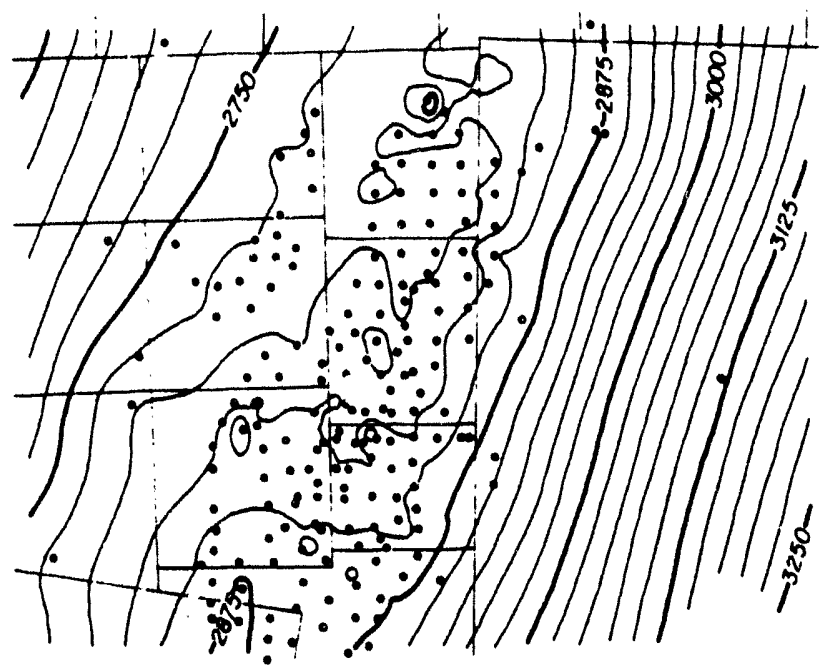

Upper Government Wells
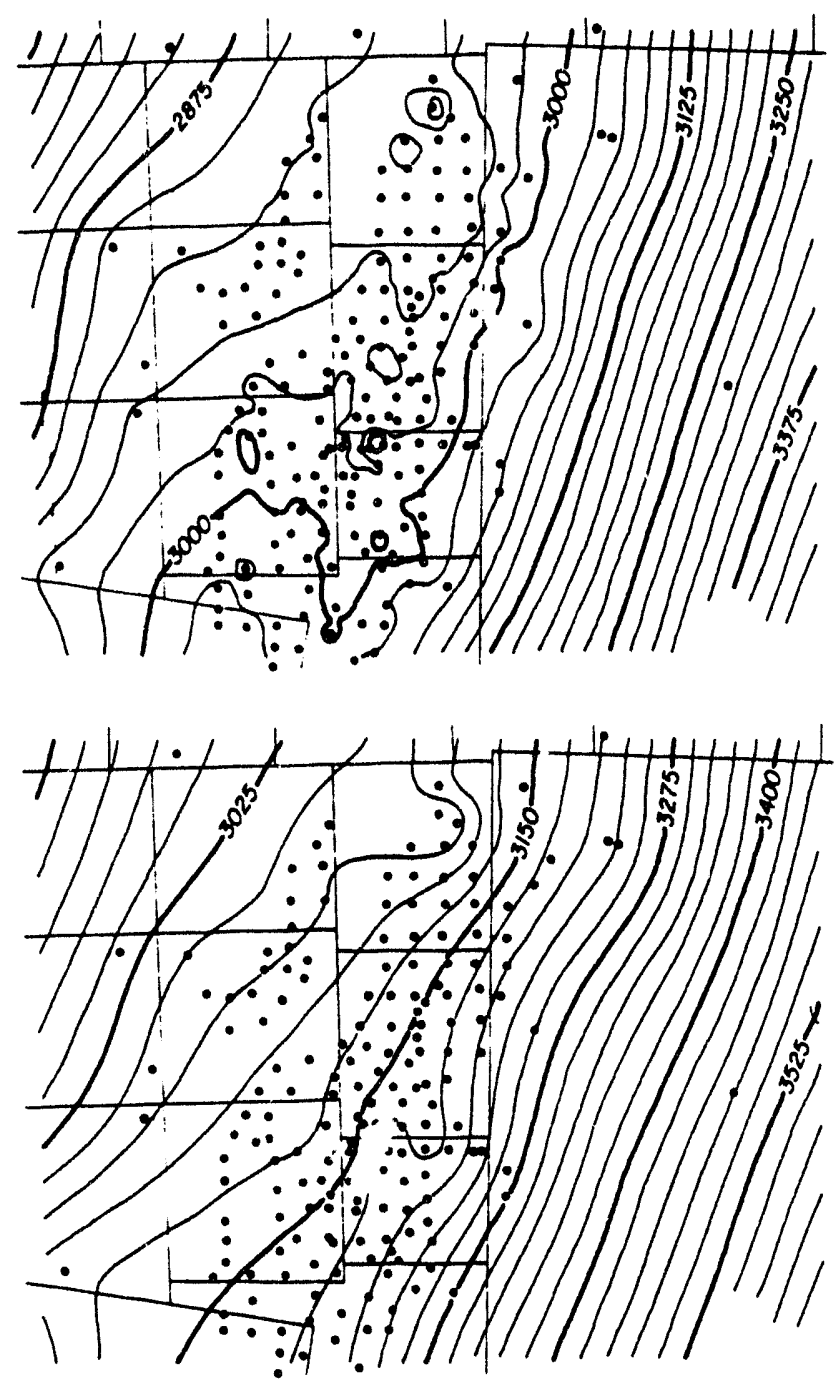

Prodo

Upper Loma Novio

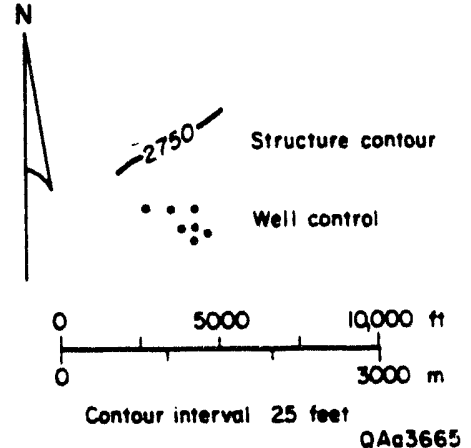

Figure 6. Structure-contour maps of Upper Covernment Wells, Upper Loma Novia, and Prado reservoirs, Prado field. Development of structural nose in field area is a result of drape compaction over thick, sand-rich Middle Loma Novia reservoirs. 


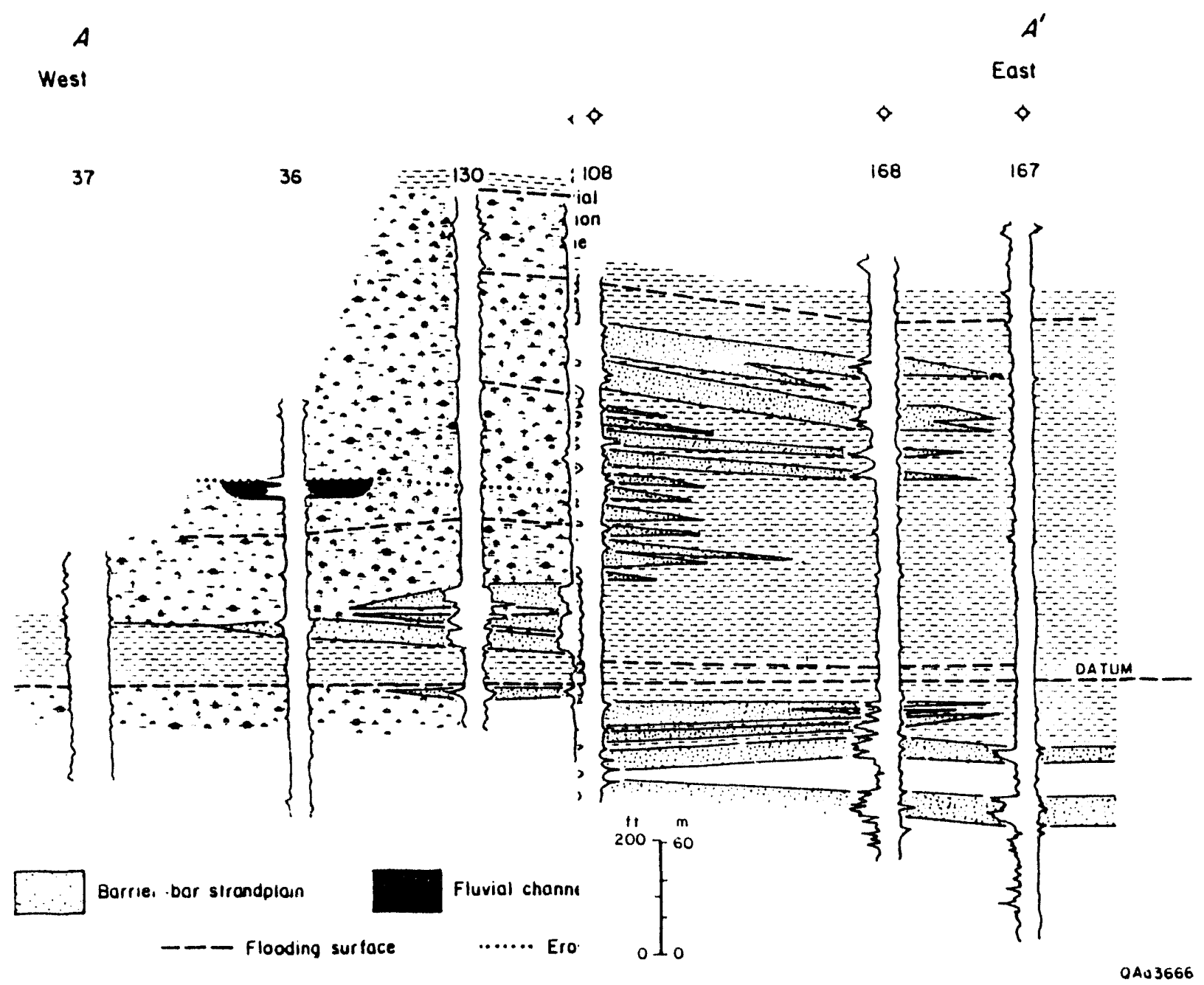

Fig̨r

sal 


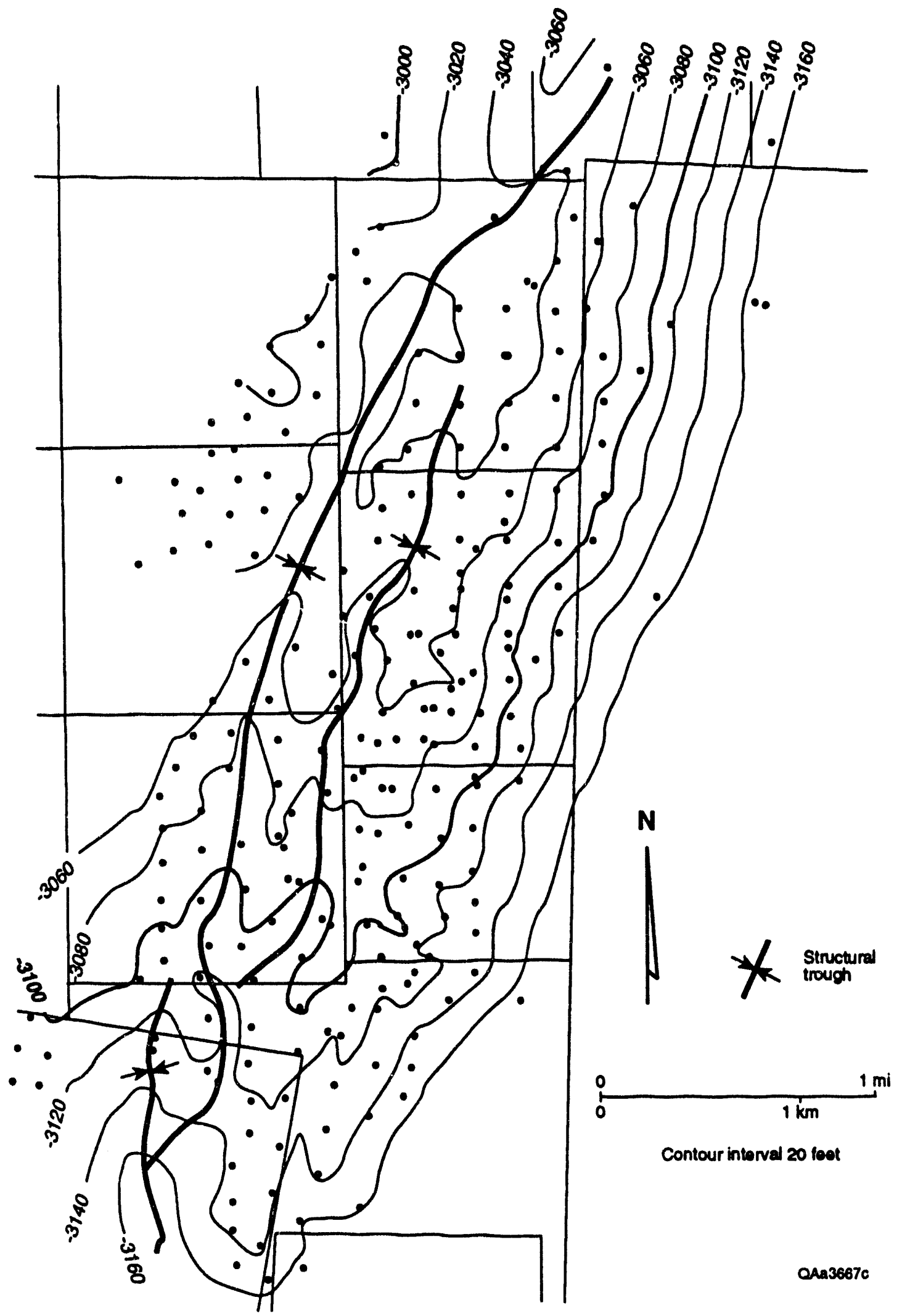

Figure 8. Structure-contour map of top Middle Loma Novia II sandstone. A structural trough on the updip margin of the field is another example of drape compaction over zone between mud-rich lagoonal facies updip and sandrich barrier facies downdip. Modified from Railroad Commission of Texas docket no. 4-55,323. 
Novia II sandstone that illustrates a series of gentle folds (amplitude of $10 \mathrm{ft}$ ) striking north-northeast and open to the south. The folds affect the structural level of the tops of horizons from the Middle Loma Novia through the Upper Government Wells. A dip-oriented structural cross section across the updip part of the field illustrates monoclinal dip on the top of the underlying Prado sandstone, whereas younger intervals are structurally low along the updip part of the field and are structurally high along the central axis of the field (fig. 9). The cross section (fig. 9) shows that the transition from the structure trough of the fold to the crest is associated with both a rapid increase in thickness and facies change in the Middle Loma Novia interval. The trough of the syncline is clearly associated with the updip pinch-out of relatively thick sand-rich, back-barrier sandstones into relatively mudstone-rich lagoonal sediments. The facies change is associated with changes in the thickness of the Middle Loma Novia interval toward the central axis $\mathrm{cf}$ the field. The decrease in percentage sandstone allowed greater compaction of mudstonerich sediments along the axis of the syncline. The syncline marks a distinct line of facies change from relatively sand rich back-barrier facies basinward to relatively mud rich lagoonal facies landward of the syncline.

\section{Depositional Framework}

A series of reports describe the stratigraphic nomenclature (Sellards and others, 1932; Murray and Wilbert, 1950; Eargle, 1959), depositional systems (Fisher and others, 1970; Kaiser, 1974; Kaiser and others, 1980), and resource distribution (West, 1963; Fisher and others, 1970; Kaiser, 1974; Kaiser and others, 1980; Galloway and others, 1983) of the Eocene Jackson Group in South Texas. The Jackson Group includes the section above the Eocene Yegua Formation and below the Oligocene Frio Formation. Murray and Wilbert (1950) described the stratigraphy of the Jackson Group in the central Gulf region, and Eargle (1959) described the stratigraphy in the south-central Texas region. In the South Texas region, from Atascosa and Live Oak Counties to the Rio Grande, the section of the Jackson Group that contains the productive sandstones in Prado field is informally referred to as the lower Jackson (Kaiser, 1974). Although a detailed treatment of the formal stratigraphic nomenclature of the Jackson Group is beyond the scope of this 


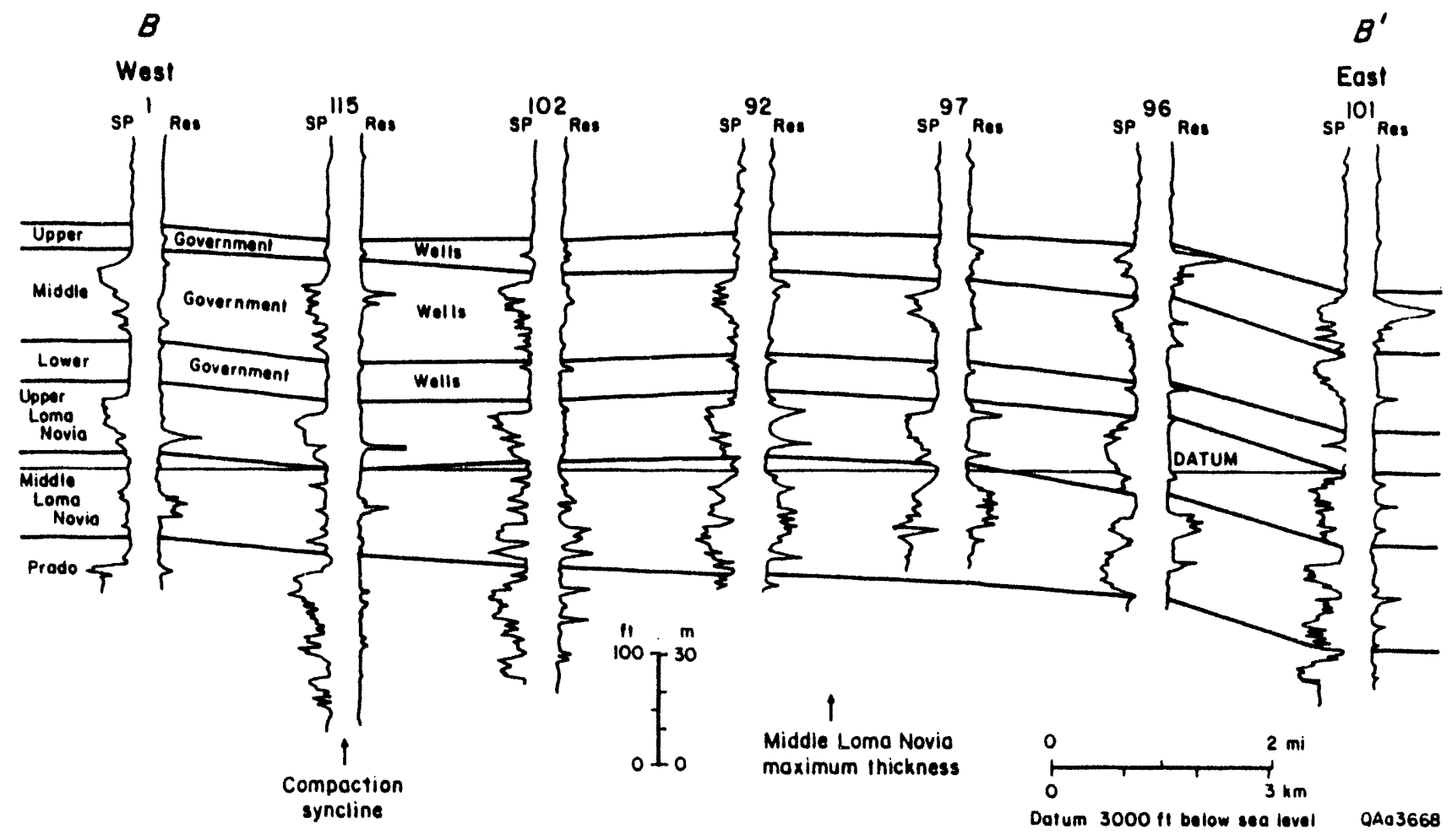

Figure 9. Structural cross section showing structural crest over sand-rich Middle Loma Novia interval. 
paper, a brief description of the informal names of laterally extensive sandstones is helpful for understanding the stratigraphic framework. West (1963) described the informal nomenclature of the strike-persistent sand bodies. In South Texas, the Jackson Group includes 1,000 to 1,500 ft of sandstone and mudstone. The lower Jackson contains three to five strike-elongate sand bodies up to $60 \mathrm{ft}$ thick interbedded with subequally thick mudstones and underlain by 50 to $200 \mathrm{ft}$ of regionally extensive mudstone immediately overlying the Yegua Formation. These sandstone bodies are informally referred to in ascending order as the Pettus, Mirando, Loma Novia, and Government Wells sandstones. A regionally extensive mudstone sequence 400 to $600 \mathrm{ft}$ thick separates the sandstones of the lower Jackson from Cole sandstones in the upper Jackson. Jackson Group sand bodies typically are laterally persistent, strikeoriented sandstones that grade updip and downdip into mudstone. A regional net-sandstone map (Kaiser and others, 1980) of the lower Jackson in South Texas (fig. 10) illustrates the linear, strike orientation of the sandstone trends. In Zapata and Jim Hogg Counties, two linear high-percentage sandstone trends are apparent-an updip trend along the Zapata/Jim Hogg County line and a downdip trend in central Jim Hogg County where Prado field (15) is located. These sands are the framework of the South Texas barrierbar strandplain system (Fisher and others, 1970).

Fisher and others (1970) first described the Jackson Group in terms of three-dimensional assemblages of component depositional systems and genetic depositional facies (Fisher and McGowen, 1969). In the South Texas region, Fisher and others (1970) describe three depositional systems: the South Texas strandplain-barrier bar system, the South Texas lagoonal-coastal plain system, and the South Texas shelf system. The South Texas strandplain-barrier bar system is composed primarily of strike-trending sand bodies interbedded with marine and lagoonal mudstones. Landward of the strandplain-barrier bar system, the lagoonal-coastal plain system is composed primarily of mudstone and minor sandstone. Gulfward of the strandplain-barrier bar system, the South Texas shelf system is composed of marine muds derived from the Fayette fluvial-delta system to the northeast. For the purposes of this report, the South Texas depositional systems will be integrated and the predominantly niudstone lagoonal and shelf systems will be described as facies within the framework of the barrier-bar strandplain system. 


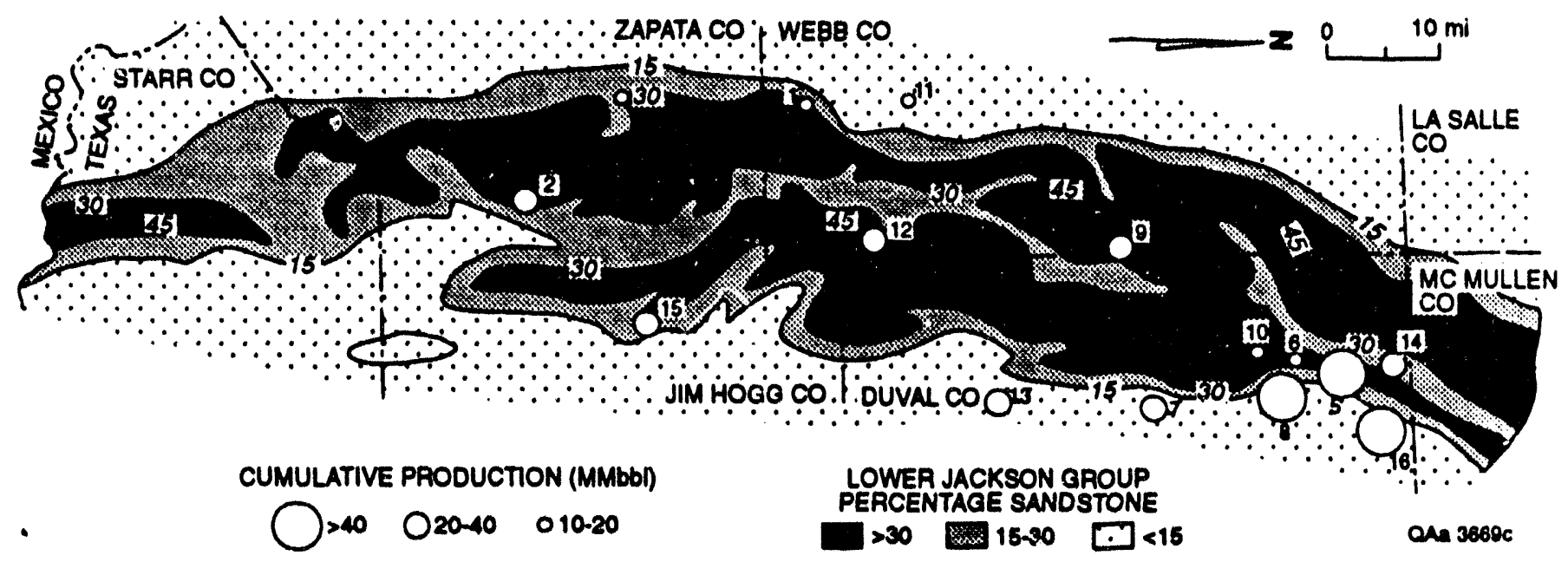

Figure 10. Percent-sandstone map of lower Jackson Group and distribution of major Jackson oil reservoirs. Numbers refer to specific fields located in figure 1. Modified from Kaiser and others (1980). 
Updip pinch-outs of strike-elongate, Jackson Group sand bodies have been targets for shallow hydrocarbon exploration for over 70 years (West, 1963). Prado field exhibits the trap style of updip sandstone pinch-out that is typical of Jackson Group reservoirs. The production and reservoir geology of oil and gas fields in the Jackson Group have been described for individual fields (Schultz, 1986; Hyatt, 1990; Hamilton, in press) and groups of fields (West, 1963; Fisher and others, 1970; Galloway and others, 1983; Seni and Walter, in press). According to Galloway and others (1983), average porosity and permeability for the largest Jackson-Yegua barrier/strandplain reservoirs are 31 percent and $604 \mathrm{md}$, respectively. A regional cross section shows the overall pattern of updip pinch-out of Jackson and Yegua sandstones across the South Texas region (fig. 7). Even from the wide spacing of the regional cross section (fig. 7), the localization of oil and gas fields by the updip pinch-out of reservoir sandstones is evident. Prado field provides an excellent opportunity to analyze local controls on hydrocarbon entrapment because of the wealth of subsurface data. Prado field has two interesting aspects (1) relatively distal position within the overall trend of lower Jackson production and (2) interesting contrast in heterogeneity among various reservoir sand bodies. The reservoir sand bodies at Prado field include typical broad belts of upward-coarsening barrier/strandplain sandstone, as well as more irregular, narrower belts of complex sand bodies that include upward-fining as well as upward-coarsening sandstones.

\section{Sand-Body Architecture and Depositional Facies}

In the Prado field area, the lower Jackson is divided into six genetic depositional sequences (fig. 9). The sequences are separated by subregional flooding surfaces within mudstones that form the upper and lower boundaries of the genetic depositional sequence (Galloway, 1989). Each of these genetic depositional sequence includes a subregional sand body that is a hydrocarbon reservoir at Prado field. Sequence boundaries were identified and correlated on the basis of the lowest resistivity markers with regional mudstones (fig. 9). Low-resistivity marker zones are interpreted to represent marine condensed sections within the shelf mudstones. Productive sandstones of the lower Jackson Group in the Prado field area of South Texas comprise a series of six, seaward-stepping, progradational parasequence sets that 
downlap a marine flooding surface on the top of the Yegua Formation (fig. 7). Dense well control (4550 wells $/ \mathrm{mi}^{2}$ ) conclusively demonstrates that individual sandstone sequences comprise multiple sandrich facies in belts 5 to $15 \mathrm{mi}$ wide and extending greater than $50 \mathrm{mi}$ along strike. Strike (fig. 11) and dip (fig. 12) cross sections within Prado field illustrate lateral continuity of individual sandstones and consistent trends in SP log patterns. The dense distribution of wells gives substantial conviction to the upward-fining correlations. Younger sand bodies (Upper Government Wells, Middle Government Wells, and Upper Loma Novia) are laterally continuous in a strike direction and typically comprise upwardcoarsening textural trends. In contrast, the older sand bodies (Middle Loma Novia and Prado) typically comprise complex packages of upward-fining and upward-coarsening sandstone and mudstone. Within the area of the field, the Upper Government Wells and Middle Loma Novia sand bodies pinch out updip. Both updip and downdip pinch-out of all other productive sand bodies is demonstrated with well control just outside the field proper.

The vertical stacking relationship of the Middle Loma Novia, Upper Loma Novia, Middle Government Wells, and the Upper Government Wells reservoirs (from oldest to youngest) is evident from stacked percentage-sandstone maps of Prado field (fig. 13). The Prado reservoir was not mapped because most of the wells did not penetrate the entire thickness of that reservoir. The Middle Loma Novia reservoir exhibits the narrowest extent of greater than 50 percent sandstone. The breadth ranges from 3,000 to $7,500 \mathrm{ft}$. At its narrowest reach, all sandstone within the Middle Loma Novia interval is confined within a belt $5 \mathrm{mi}$ wide. The updip limit of production from the Loma Novia reservoirs coincides roughly with the line of 15 percent sandstone. The upward-coarsening Upper Loma Novia is considerably wider than the Middle Loma Novia. The 50 percent sandstone line extends beyond the field limits to a width of 5 to $8 \mathrm{mi}$. The line of maximum sandstone percentage in the Upper Loma Novia prograded just downdip of the maximum sandstone line in the underlying Middle Loma Novia (fig. 14). Sandstone in the Middle Government Wells is widely distributed, similar to that of the Upper Loma Novia. The sandstonepercentage map of the upper Government Wells illustrates the basinward progradation of the area of maximum sandstone thickness. The axis of maximum sandstone percentage from prograded basinward 1 to $2 \mathrm{mi}$ (fig. 14) from the oldest Middle Loma Novia to the youngest Upper Government Wells. 


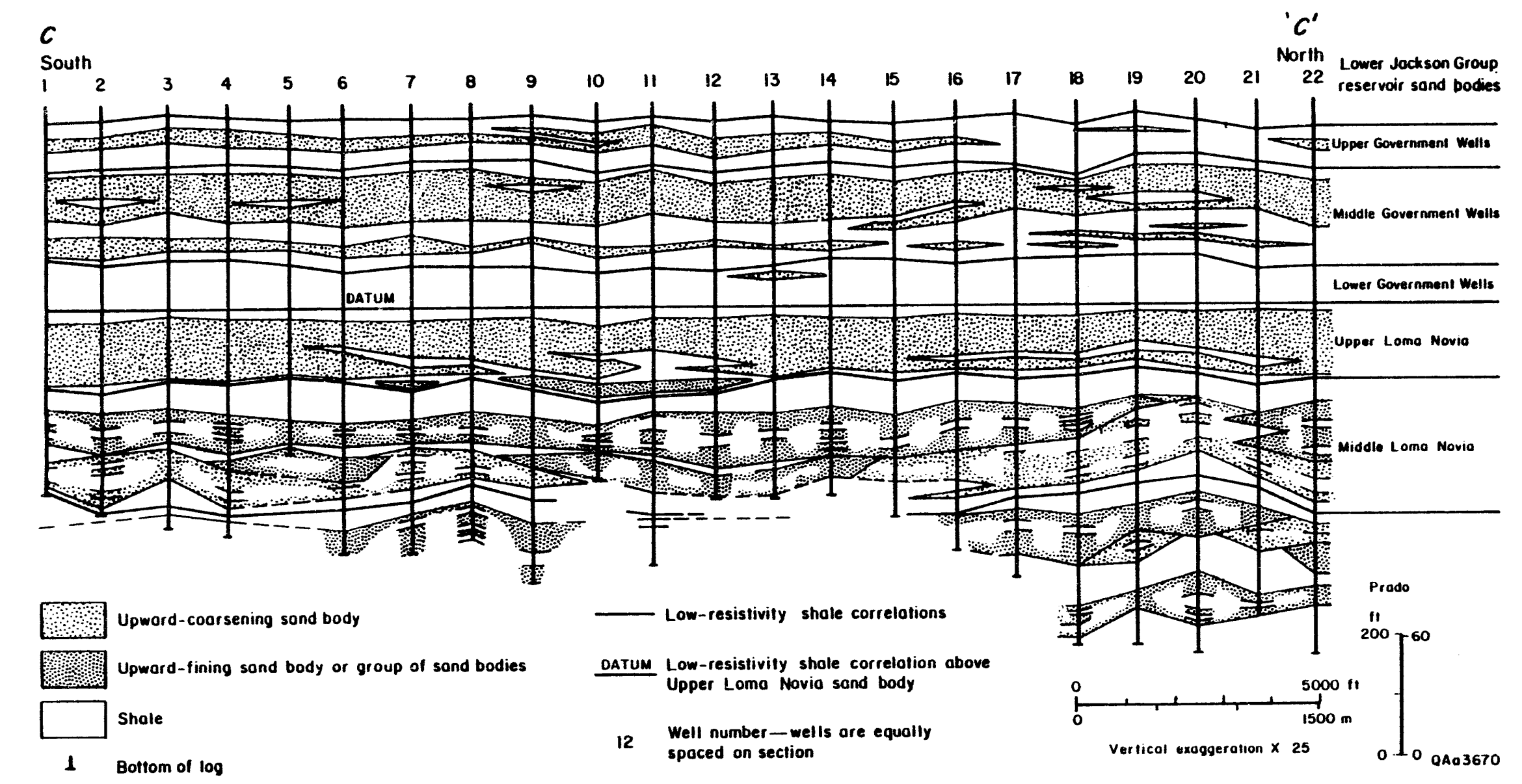

Figure 11. Strike-oriented cross section, Prado field, showing correlation of mapping units and distribution and character of reservoir sandstones. Upper Government Wells, Middle Government, and Upper Loma Novia reservoir sandstones are characteristically upward-coarsening continuous sand bodies. In contrast, Middle Loma Novia and Prado reservoir sandstones are characteristically complex packages of upward-fining as well as upward-coarsening sand bodies. 


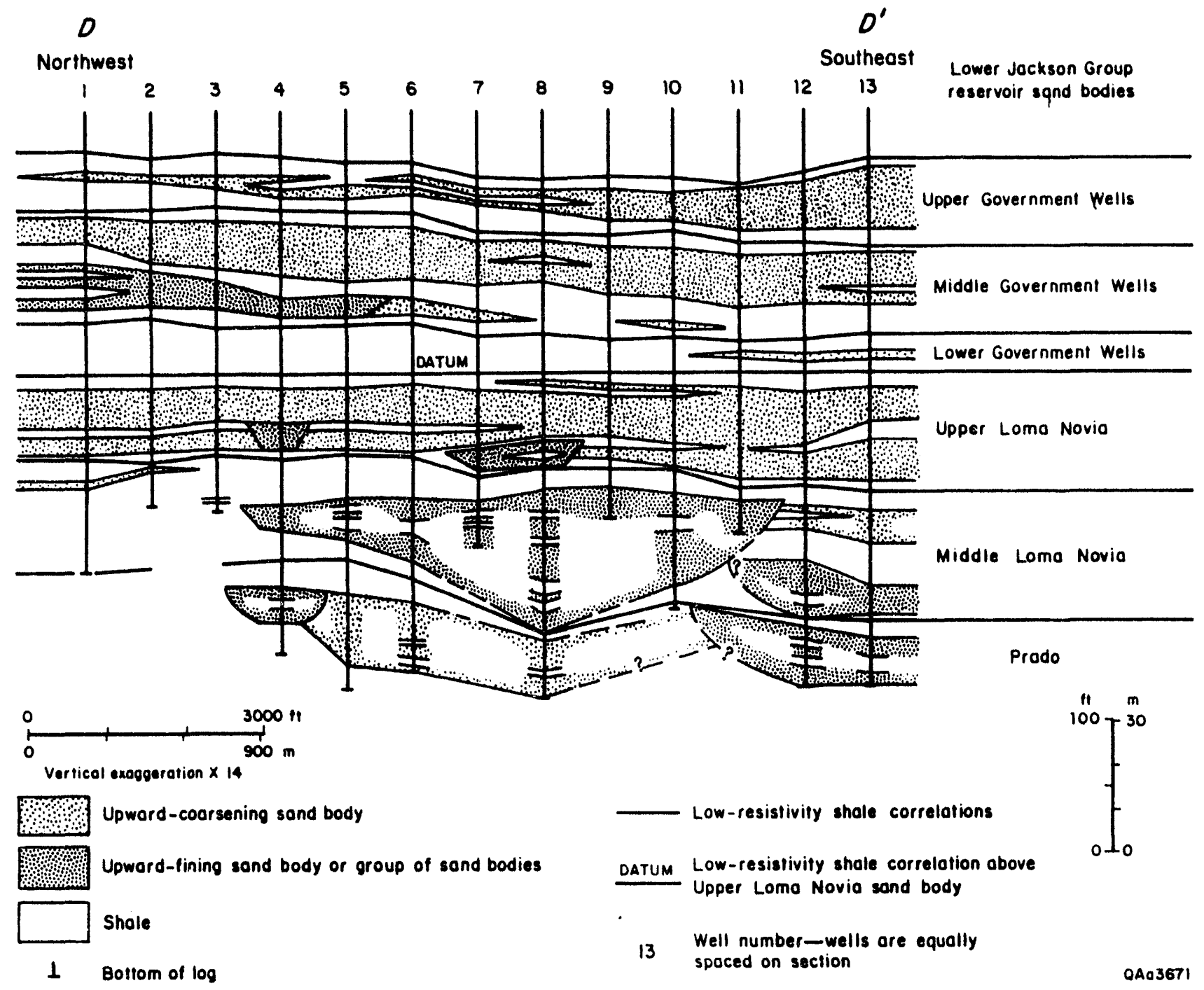

Figure 12. Dip-oriented cross section, Prado field, showing correlation of mapping units and distribution and character of reservoir sandstones. 


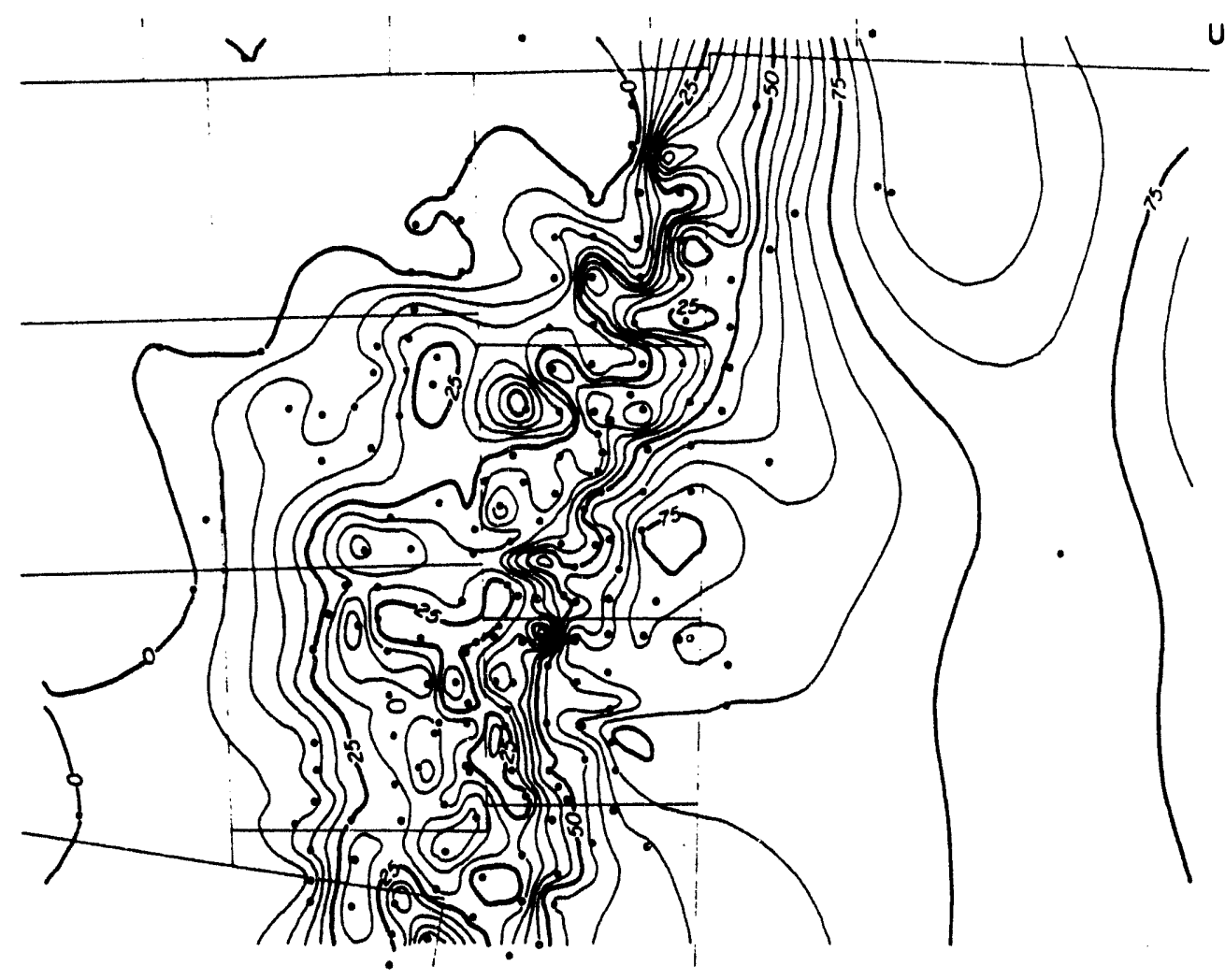

Upper Government Wells

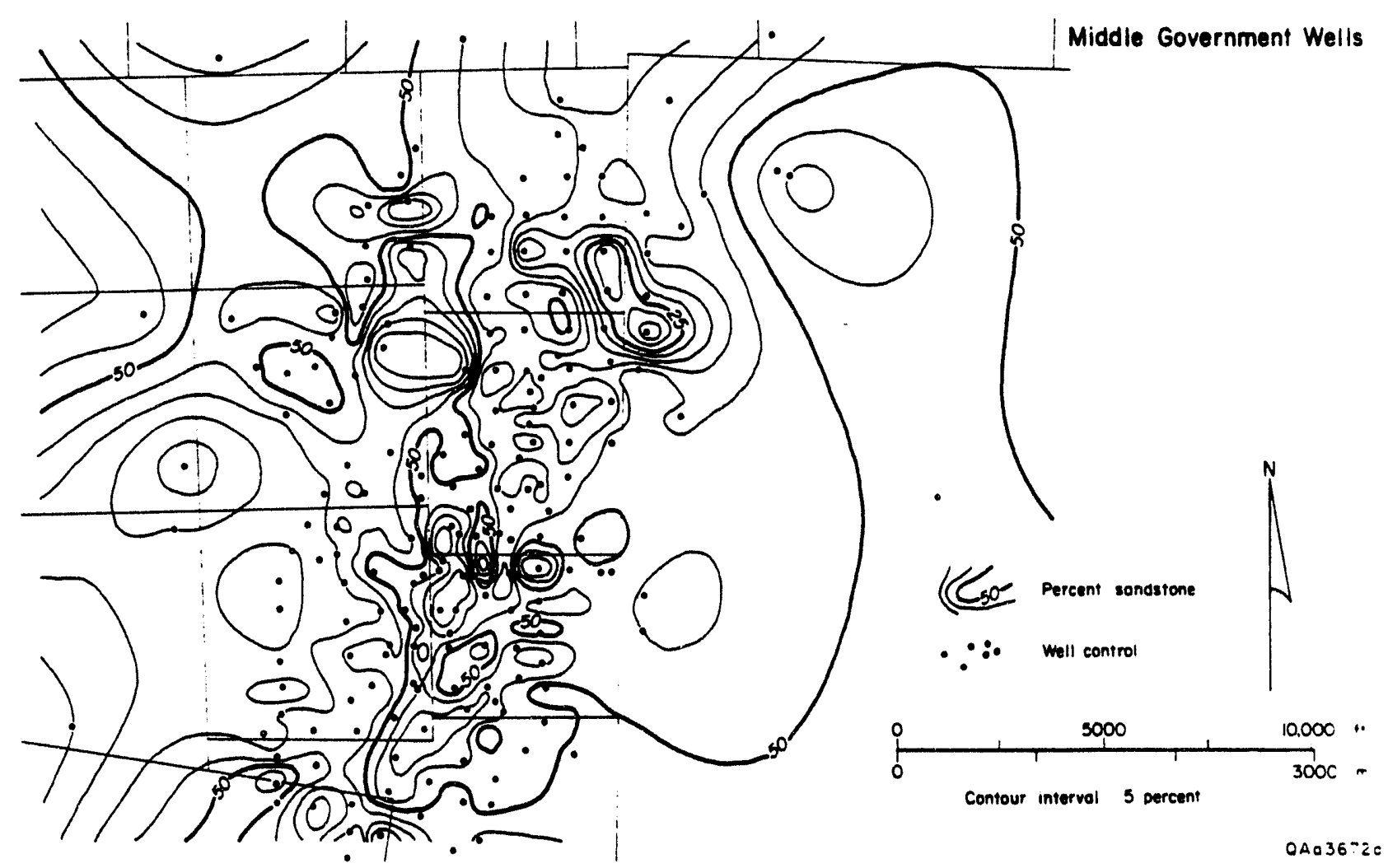

Figure 13. Percentage-sandstone maps for Upper Covernment Wells, Middle Government Wells, Upper Loma Novia, and Middle Loma Novia reservoir sandstones, Prado field. Maximum percentage sandstone for all intervals trends north-northeast. The area of greater than 75 percent sandstone prograded downdip from the Middle Loma Novia to the Upper Government Wells. 

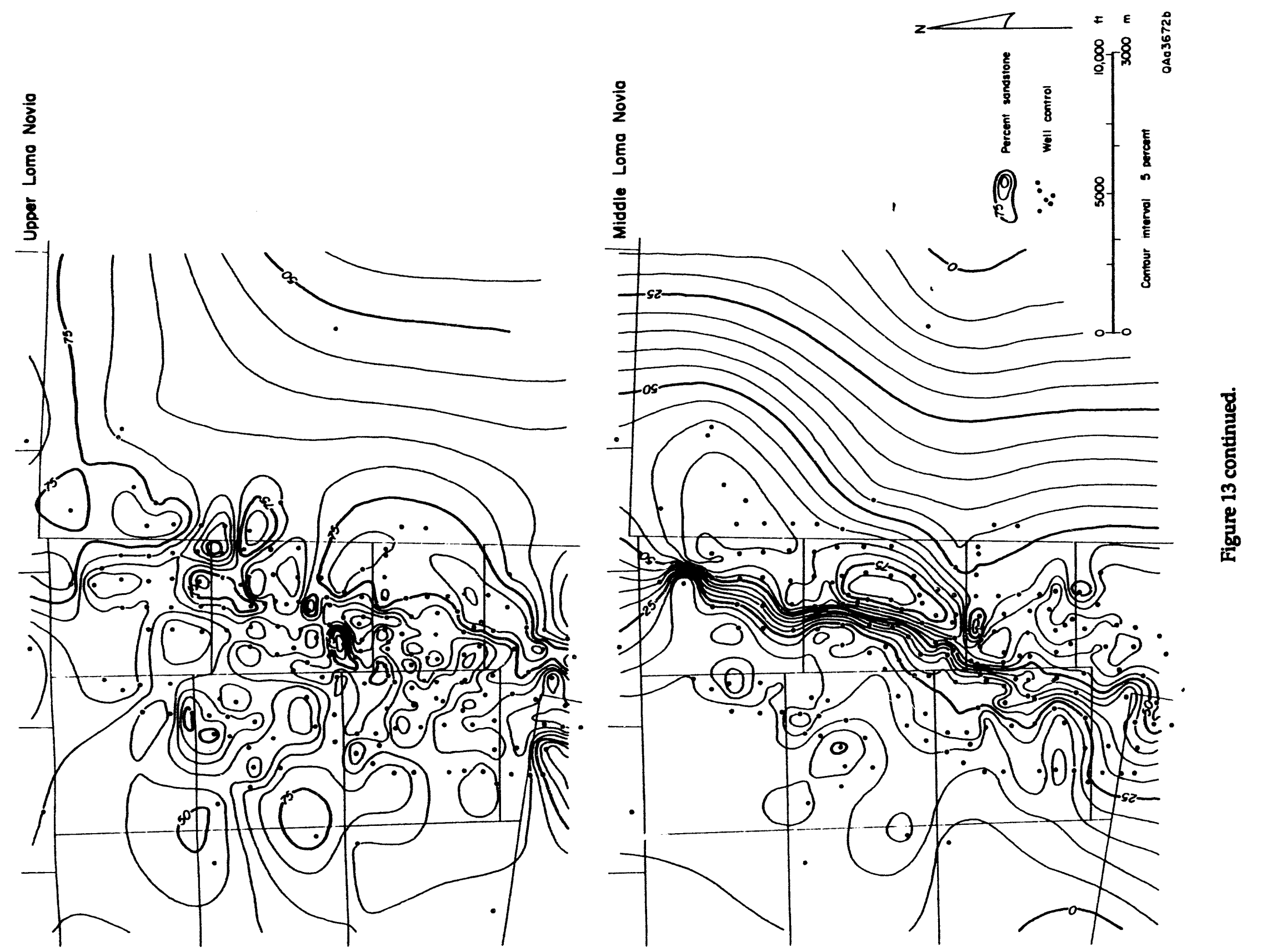

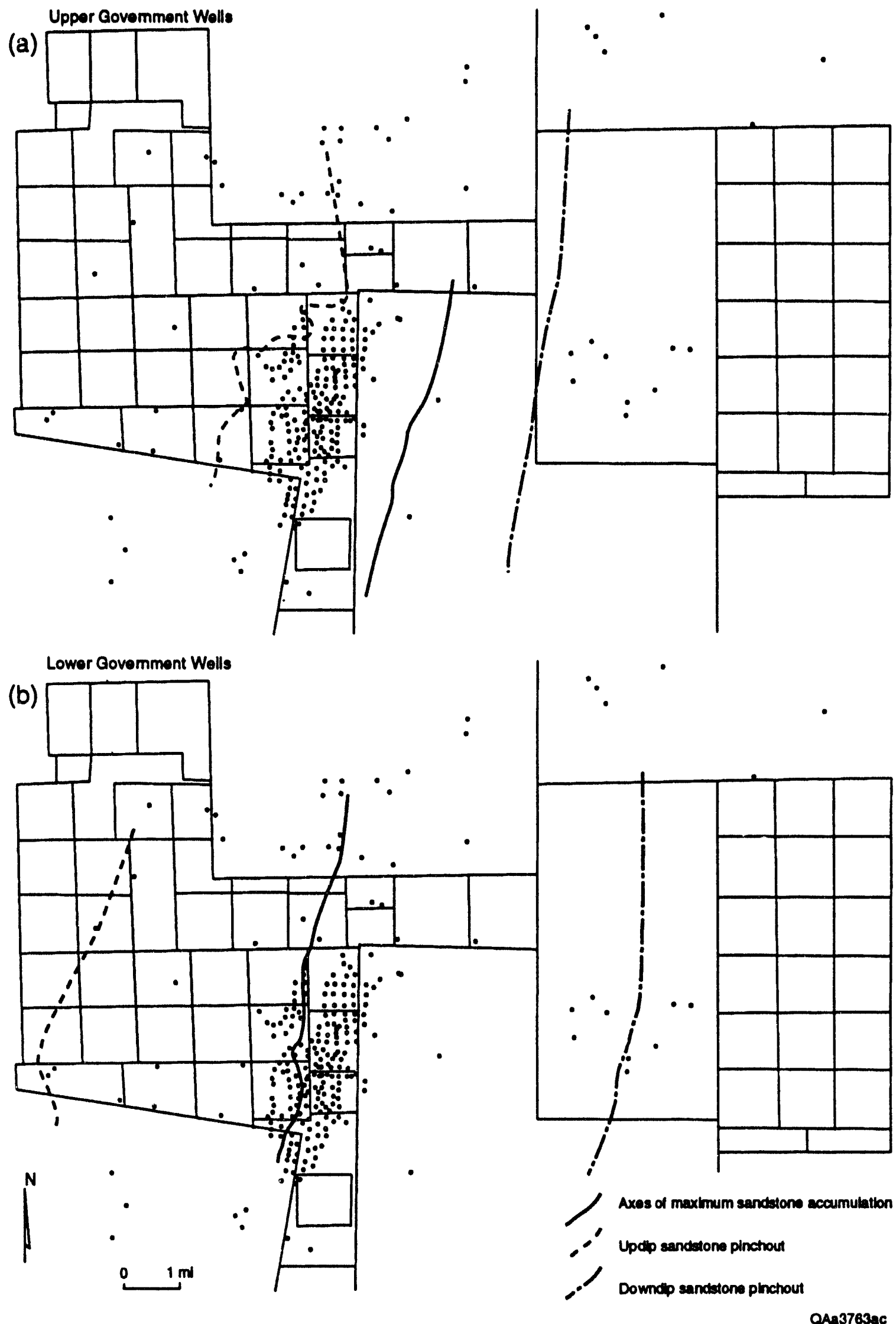

Figure 14. Map of axis of maximum sandstone accumulation and updip and downdip lines marking sandstone pinch-outs. 

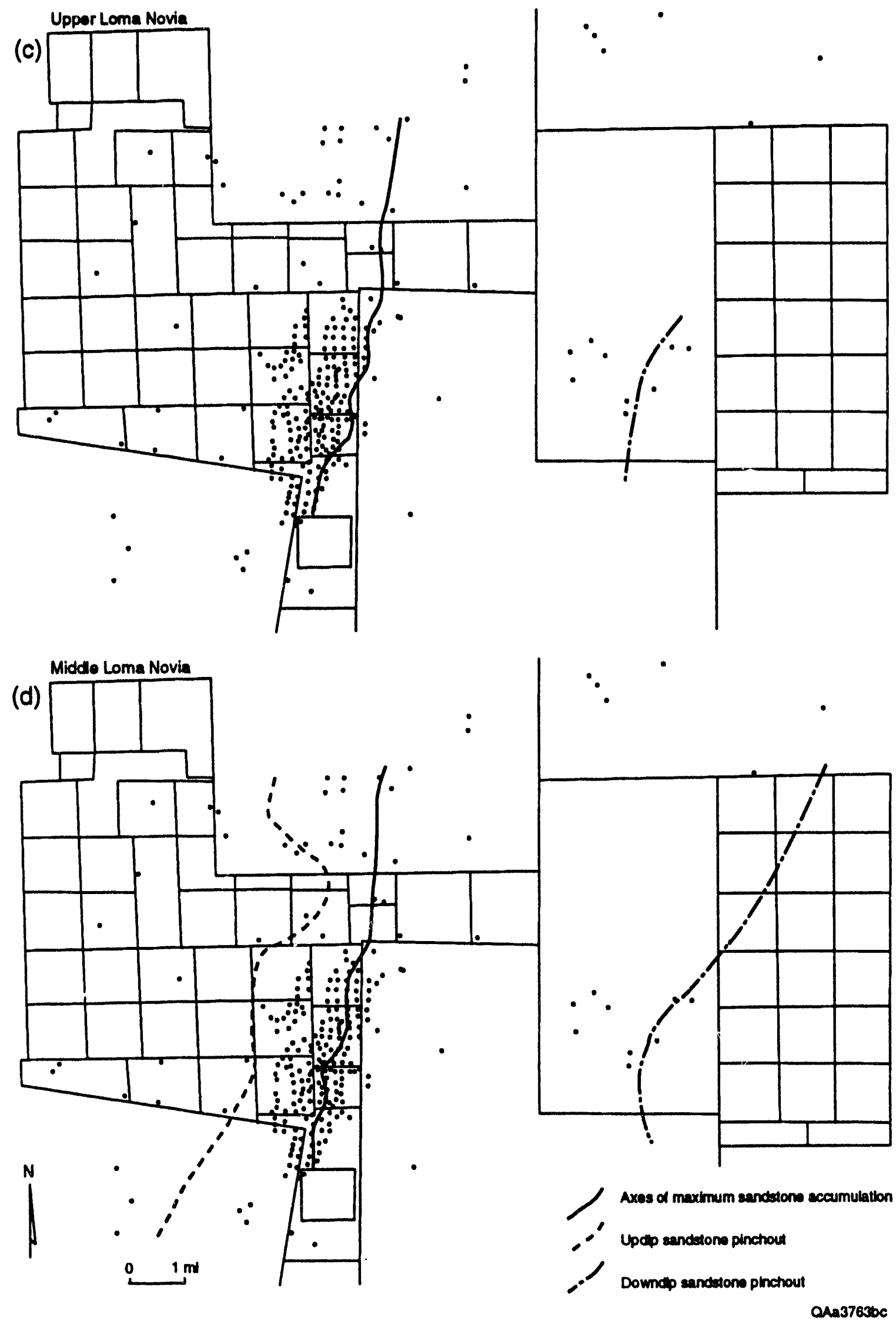

Figure 14 continued. 
Regional or local unconformities as a result of rapid relative sea-level falls are difficult to identify solely on the basis of SP response and well log character in the absence of core. However, a possible unconformity surface was identified in association with (1) isolated channel sandstone geometries and (2) basinward facies shift of $15 \mathrm{mi}$ for lower Jackson sandstones overlying shoreline facies. The basinward shift of lower Jackson sandstones can be explained as the forced regression of shoreline position during base-level lowering or possibly during influx of volcaniclastic sediments. This is interpreted to be the cause of the separation of an updip and a downdip strike-oriented sandstone axis on the net-sandstone map of the lower Jackson (fig. 10). Once the forced regression established lower Jackson shorelines in the Prado field area, then shoreline progradation occurred much more gradually and at a diminished rate.

\section{Reservoir Models}

Reservoir sandstones at Prado field are classified in two end-member depositional models as a result of variations in the types of barrier systems that have developed: (1) an unsegmented barrier-bar model and (2) a tidal-inlet fill model. Middle Government Wells, and Upper Loma Novia reservoirs are characterized by the unsegmented barrier-bar model, whereas the Middle Loma Novia and Prado reservoirs are characterized by tidal-inlet fill model. The Upper Government Wells is intermediate, having characteristics of both models. The younger, unsegmented barrier-bar sand bodies overlie the two older tidal-inlet fill sand bodies. The unsegmented barrier-bar reservoirs primarily produce gas by virtue of their structurally high position, whereas the lower tidal-inlet fill sandstones produce oil and some gas.

Galloway and Cheng (1985) described barrier-island depositional systems of the Frio Formation in terms of the architectural elements of a barrier-island sand body (fig. 15). Principal sand-rich depositional environments of the barrier-island sand body include barrier core, inlet fill, flood-tidal delta, washover fan and barrier-flat, and shoreface. These same architectural elements are recognized in Prado field. 

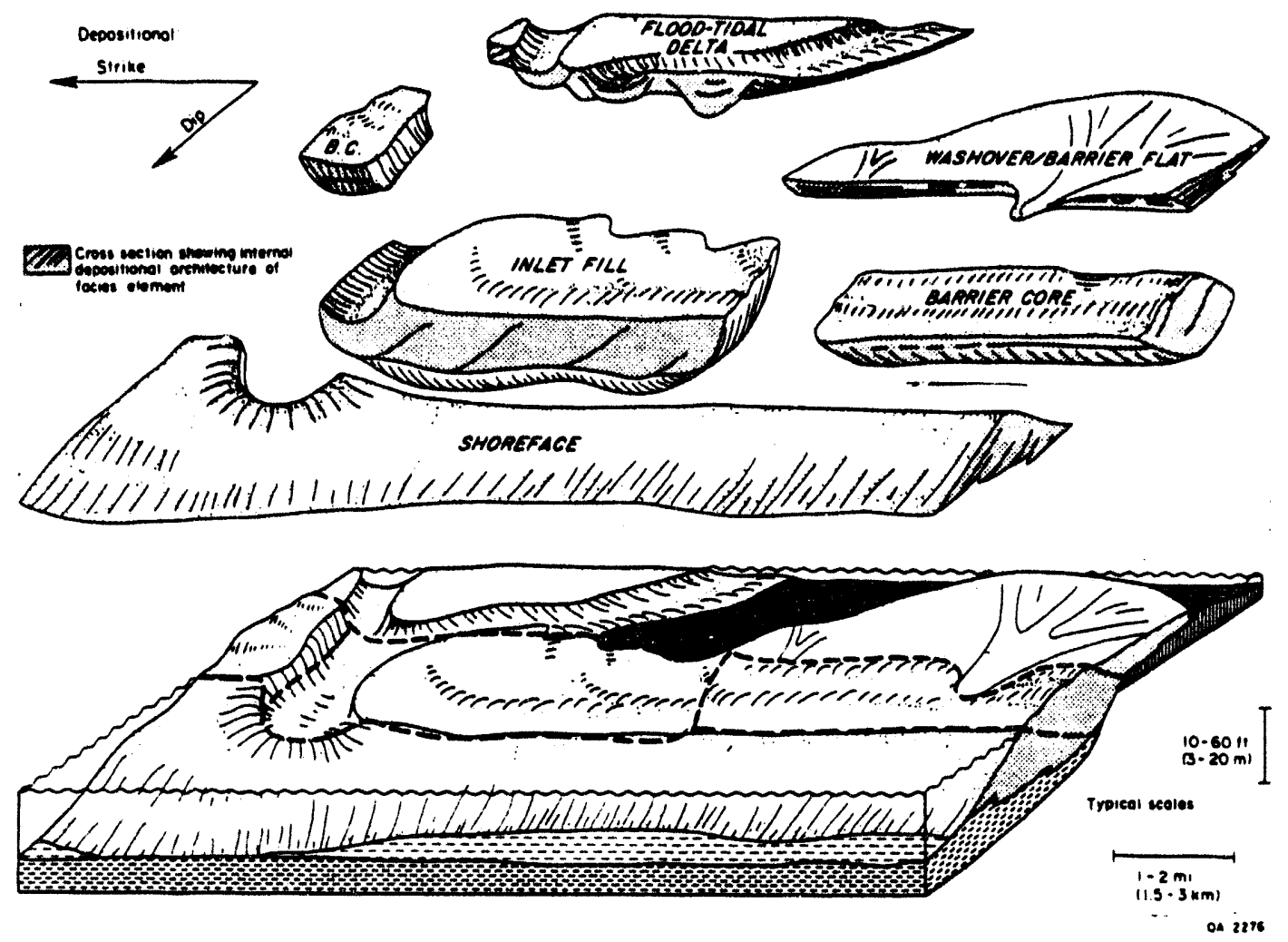

Figure 15. Component depositional facies of barrier-bar sand body. After Galloway and Cheng (1985). 
Log Facies

Log facies have been identified for each of the main reservoir sand bodies at Prado field (fig. 16) and are useful for differentiating reservoir characteristics and models (figs. 11 and 12). Log facies are defined on the shape of the SP curve (Krueger, 1968; Galloway and Cheng, 1985; Tyler and Ambrose, 1985, 1986; Tyler and others, 1986; Ramos and Galloway, 1990). The SP log is a primary, indirect record of the permeability and thus gross grain-size distribution of the strata as a function of the greater permeability of sandstones when compared to shales. Factors affecting the magnitude of the SP curve include: (1) the ratio between mud resistivity and formation water resistivity, (2) hole size, (3) depth of invasion, (4) bed thickness, (5) lithology of the strata, and (6) formation resistivity. Stratigraphic variables directly affect bed thickness, lithology, and formation resistivity.

On the basis of SP and resistivity log pattems and lateral facies associations, each of the generally upward-coarsening, progradational parasequence sets typically comprise the following facies tract from updip to downdip: A updip mudstone-rich lagoonal/back barrier/floodplain facies, B sandstone-rich shoreface and core barrier-bar and tidal inlet fill facies, and C downdip mudstone-rich shelf facies. A low-resistivity marker zone typically occurs within the basal mudstone. Facies $A$ is located updip of the sandstone-rich facies and increases in sandstone content in a downdip direction. Facies $A$ is interpreted to represent predominantly lagoonal deposits updip of the barrier bar system. Facies A1 is mudstone rich, ranging from 100 percent mudstone to mudstone that contains lignite and rare thin, spikey sandstone interbeds. Facies A1 is interpreted to represent lagoonal mudstones. Facies A2 contains mixed mudstone and spikey to thin blocky sandstone interbeds. Facies $\mathrm{A} 2$ is sandier than facies $\mathrm{A} 1$ yet is still mudstone dominated. Sandstone interbeds are less than 1 to $10 \mathrm{ft}$ thick and range from spikey to thinly blocky. A core description from facies A2 indicates a fine sandstone bed, $8 \mathrm{ft}$ thick, overlain by a 2-ft lignite. Mean permeability of the sandstone is $446 \mathrm{md}$ (range 32 to $1,900 \mathrm{md}$, horizontal permeability) and porosity is 30.6 percent (fig. 17). A thin streak of low permeability, highly cemented (indurated) sandstone occurs at 

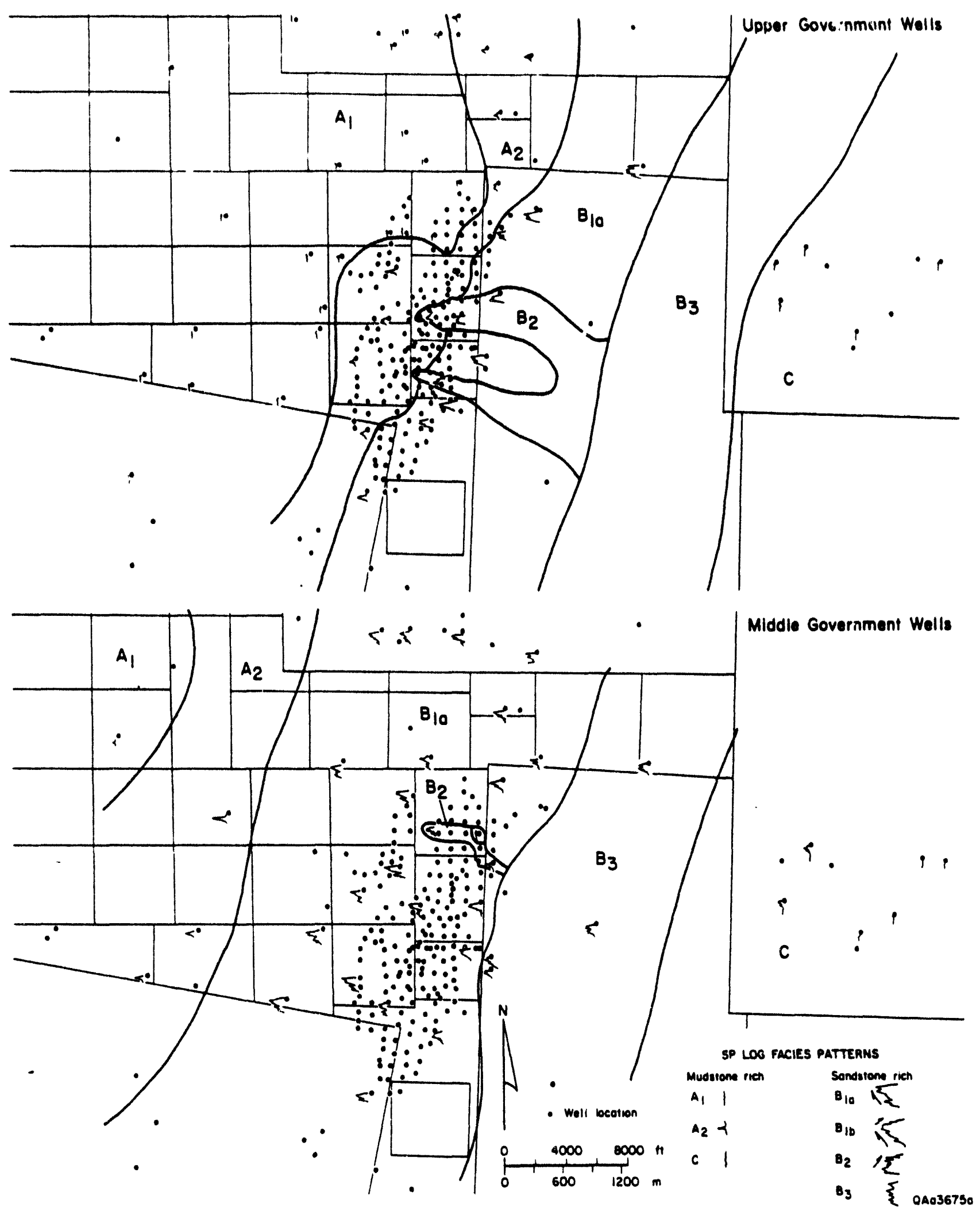

Figure 16. SP $\log$ facies of Upper Government Wells, Middle Government Wells, Upper Loma Novia, and Middle Loma Novia reservoir sandstones, Prado field. 

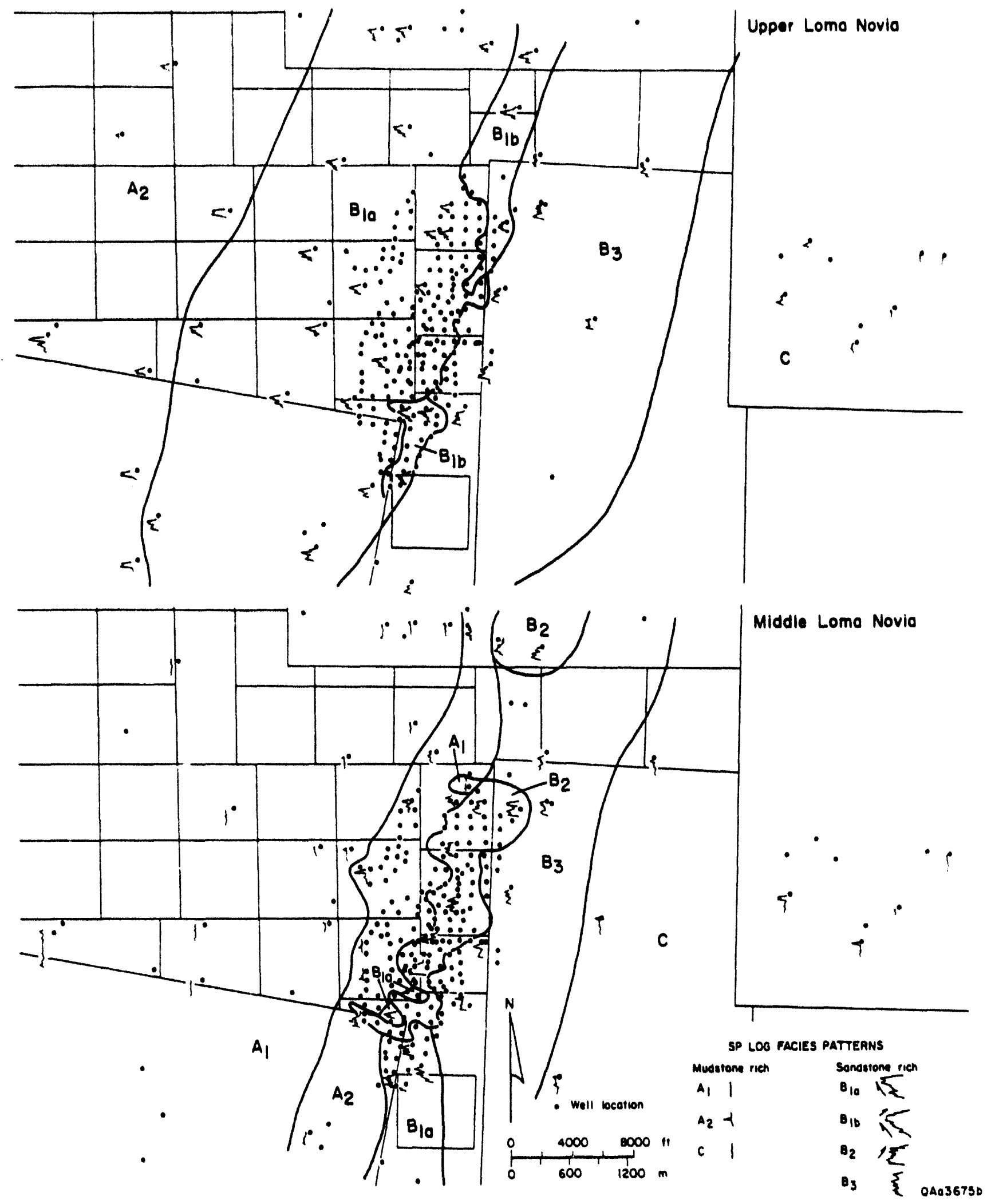

Figure 16 continued. 


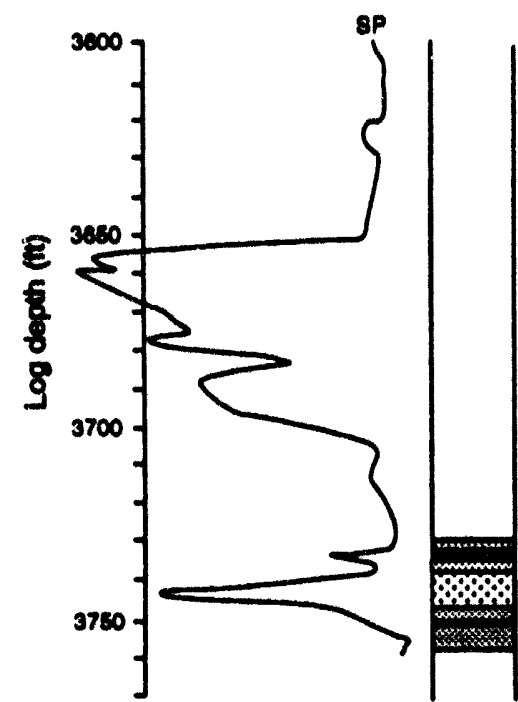

Sandatione

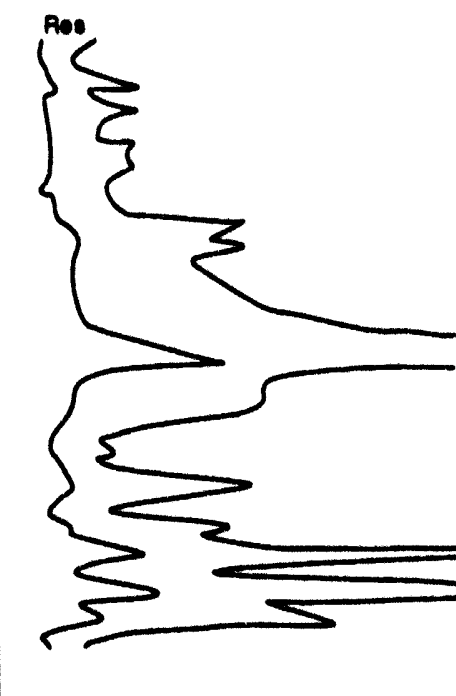

Lignite

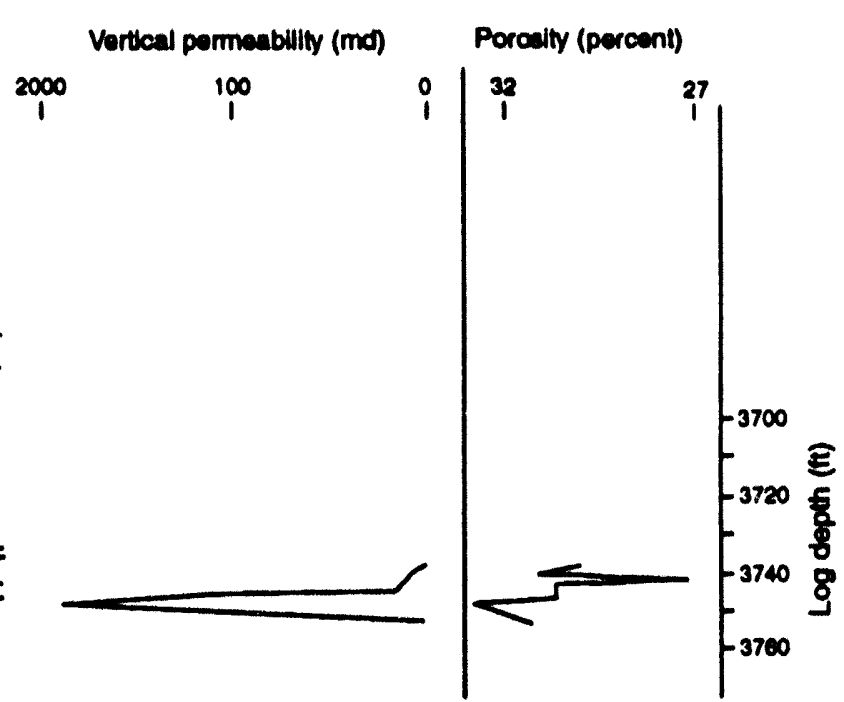

QAa36760

Figure 17. Detailed electric $\log$ and lithologic description of reservoir interval indicating thin back-barrier sandstone overlain by lignite. Porosity and permeability reveal a general upward decrease. 
the base of the sandstone. Facies $\mathrm{A} 2$ is interpreted to represent mud-rich back-barrier environments where washover sandstones have spilled into the lagoonal environment.

Facies $C$ is also a mudstone-dominated facies that ranges from 100 percent mudstone to mudstone with thin serrate sandstone interbeds. Facies $C$ is located downdip of the sandstone-rich facies and sandstone percentage decreases in a downdip direction. Thin sandstone interbeds in facies $C$ is concentrated in thin serrate bodies with more subdued SP deflection than the spikey sandstone common in facies A. Facies $C$ is interpreted to represent shelf mudstones and thin, interbedded shelf sandstones. The subdued SP response of the shelf sandstones is inferred to indicate their relatively high mudstone content as a result of bioturbation.

The sandstone-rich facies B comprise three subfacies: facies B1-widespread, sheet-like upwardcoarsening sandstone, of relatively uniform thickness; facies B2-complex upward-coarsening and upward-fining sand bodies; and facies B3-mixed serrate mudstone and sandstone. Facies B1 tends to be relatively widely distributed in a dip and strike direction, yet it still clearly grades into mudstone both updip and downdip. Facies B1a is capped by an abrupt transition into mudstone, whereas facies B1b is capped by a gradational upward-fining pattern. Facies Bla is inferred to represent a broad barrier bar of relatively homogeneous facies composition. Facies B1b is inferred to represent a flank facies of the barrier bar that was transgressed during relative sea-level rise.

Facies B2 occurs in a narrow, strike-oriented belt containing complex serrate sandstone bodies that typically comprise a lower upward-coarsening sandstone, and an upper upward-fining series of sandstones cut into upward-coarsening sand bodies. Facies B2 includes multiple, upward-fining, erosivebased, channel sand bodies that cut irregularly into the shoreface and barrier sandstones. Facies B2 exhibits rapid lateral facies change into fine-grained facies in both an updip and downdip direction. Facies B2 is inferred to represent a tidally dominated segment of a barrier bar. Subregional correlations of the sand bodies outside the field area demonstrate that facies B1 and B2 are laterally equivalent. Thus, facies B2 apparently represents a reach along a barrier bar chain where tidal inlet fill facies mark the transition between individual barrier bar segments. 
Facies $B 3$ is a mixed sandstone and mudstone facies located shelfward of the proximal, sandstonerich facies of the barrier core B1 and B2. Facies B3 is characterized by serrate upward-coarsening to somewhat blocky SP patterns containing multiple mudstone interbeds. This proximal serrate pattem represents a mixed sandstone/mudstone facies located in parallel and along strike with the barrier core but downdip of the axes of maximum sandstone accumulation. The proximal serrate sandy facies was not dip oriented, and thus was not interpreted as a tidal facies. Instead the proximal serrate sandy facies was interpreted as a proximal shoreface to lower shoreface facies.

\section{Unsegmented Barrier-Bar Reservoir Model}

The unsegmented barrier-bar sandstone sequence is characterized by shale-encased sand bodies that coarsen upward in grain size and in thickness of bed sets. Middle Government Wells, and Upper Loma Novia reservoirs are all characterized by this relatively homogeneous depositional facies (figs. 8 and 9). The barrier-bar trend of the two reservoir sandstones is 8 to $15 \mathrm{mi}$ wide, as defined by the location of the updip and downdip pinchout position (fig. 14). The similarity of SP log patterns among these barrier-bar sandstones indicates gross parallels in the depositional facies of the two reservoirs (fig. 18). The underlying mudstone-rich shelf facies are gradationally overlain by sandstones that coarsen upward and typically are abruptly overlain by lignite-bearing lagoonal mudstones. The sand-rich facies are rarely segmented by dip-oriented crossing facies, such as tidal inlet channel fill. Barrier-core facies contain the highest percentage sandstone and are characterized by blocky upward-coarsening SP profile. Mudstonerich facies occur both updip and downdip of the barrier-bar facies. Shelf facies $C$ are mudstone rich and comprise local thin muddy sandstones with suppressed SP patterns as a result of intercalated mudstone. Lagoonal facies are also mudstone rich. Proximal lagoonal facies contain thin spikey to blocky sandstones that are characteristically cleaner with longer SP deflections than equivalent thin sandstones in shelf facies. Presumably the cleaner sandstones in the lagoonal setting reflect higher energy input of sand during washover events and less post-depositional reworking by a low diversity fauna. Although the updip transition into sand-rich back-barrier facies is relatively broad, nonetheless back barrier facies 

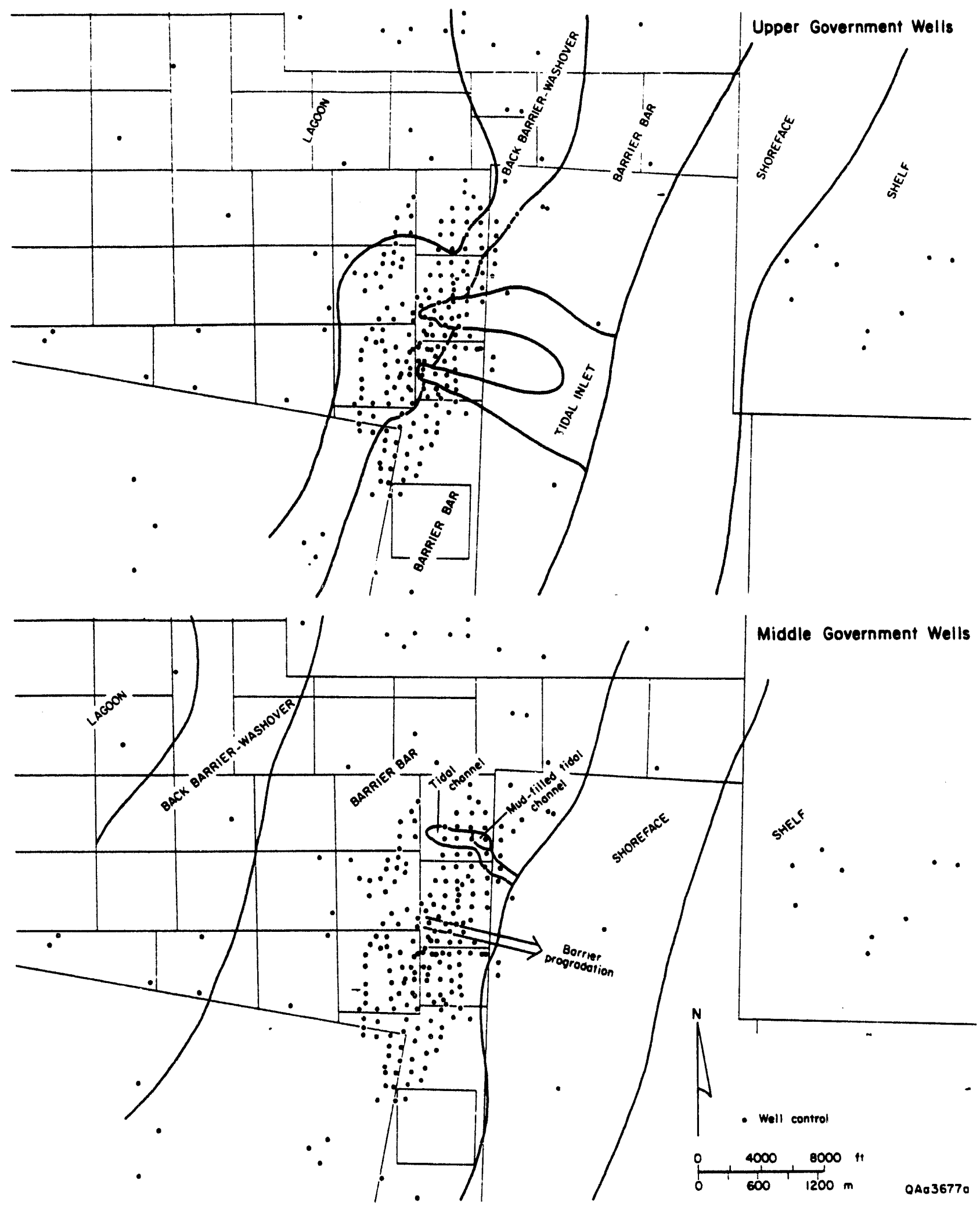

Figure 18. Depositional facies of Upper Government Wells, Middle Government Wells, Upper Loma Novia, and Middle Loma Novia reservoir sandstones, Prado field. 


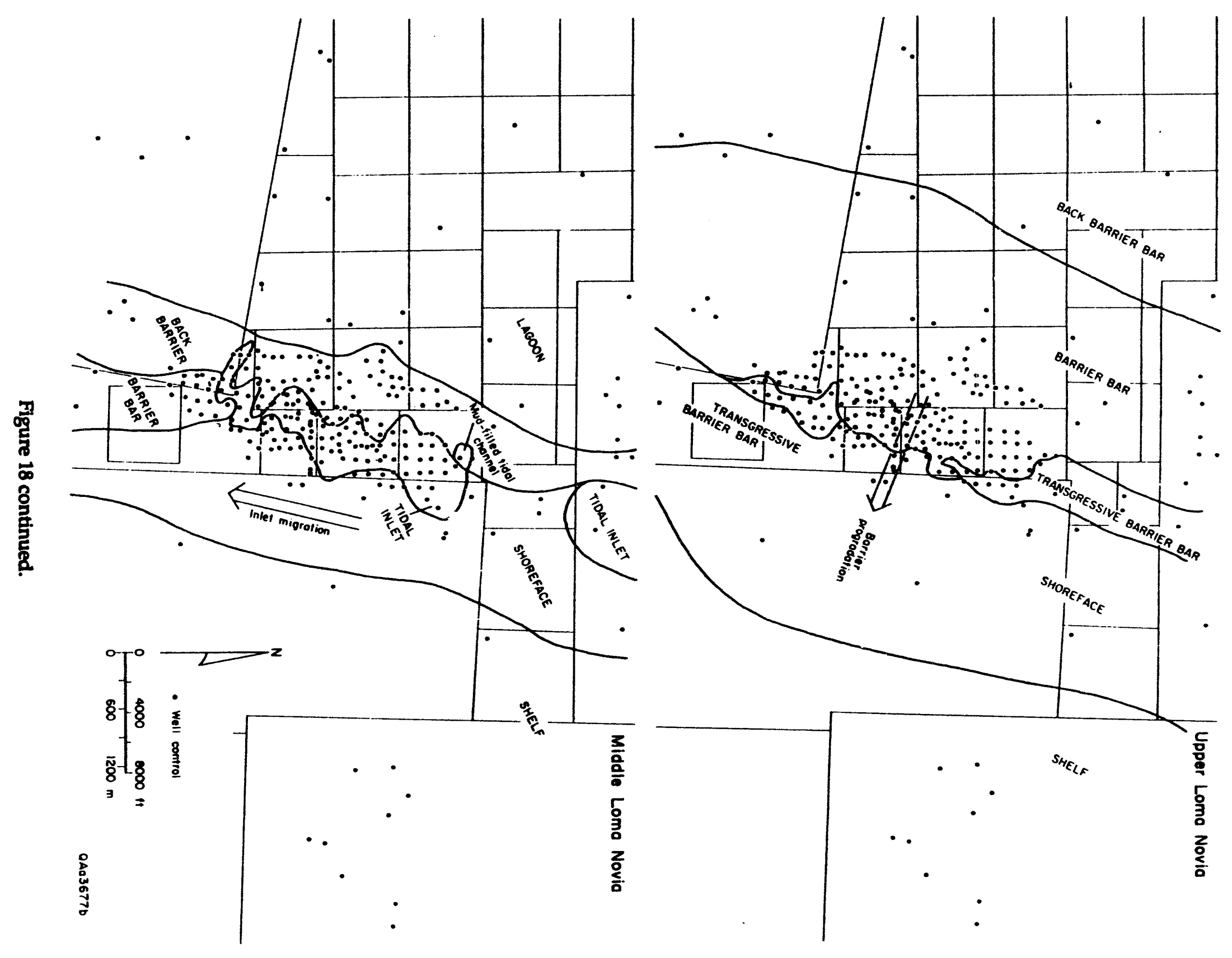


do grade into lignitic mudstones. The mudstones of the unsegmented barrier bar do appear to be somewhat sandier in the Middle Government Wells and Upper Loma Novia than equivalent lagoonal mudstones of the Upper Government Wells or the Middle Loma Novia. The positioning of updip lagoonal facies clearly identifies the sand-rich facies as barrier bars and not as sand-rich strandplains.

The upward-coarsening profile is either smooth or serrate, with multiple thinly interbedded mudstones depending on position within the facies tract. A dip-oriented structural cross section shows the log characteristics of the unsegmented barrier-bar reservoir model for the Upper Loma Novia (fig. 19). The cross section also illustrates the contrast in lateral continuity between the unsegmented barrier-bar reservoir model and the tidal-inlet fill reservoir model that characterized the underlying Middle Loma Novia. The Upper Loma Novia and the Middle Government Wells sand bodies are characterized by two separate sandstones in the updip position that are separated by a shale interval (fig. 16). The unsegmented barrier bar models are typically overlain abruptly by lignitic lagoonal mudstone. The Upper Government Wells and Middle Government Wells sand bodies show this pattem very consistently (fig. 16). Locally along the downdip margin of the barrier-bar axis, the upper Upper Loma Novia upwardfining barrier bar is replaced gradationally by an upward-fining sandstone that represents a transgressive barrier bar (fig. 19). The transgressive barrier was established on the southern and northern margins of Prado field, where barrier sands were originally thinner. The characteristic thin bed sets and absence of cut and fill indicate that tidal channel and inlet migration were minor.

The relatively homogeneous facies mosaic of the unsegmented barrier-bar reservoirs places greater emphasis on the structural component for a trapping mechanism. Sandstone-rich facies are spread widely both laterally and along strike. Scour and fill structures that cut across depositional strike, such as tidal or inlet channels, are generally lacking. The absence of migration barriers in the form of facies heterogeneities reduces the probability of identifying facies-controlled compartments in the unsegmented barrier-bar model. Permeability barriers should exist in those segments of the barrier bar that developed transgressed barrier facies containing intercalated mudstone and reservoir sandstone. Such facies occur along the downdip margin of the barrier core in the northern and southern margins of the field. 


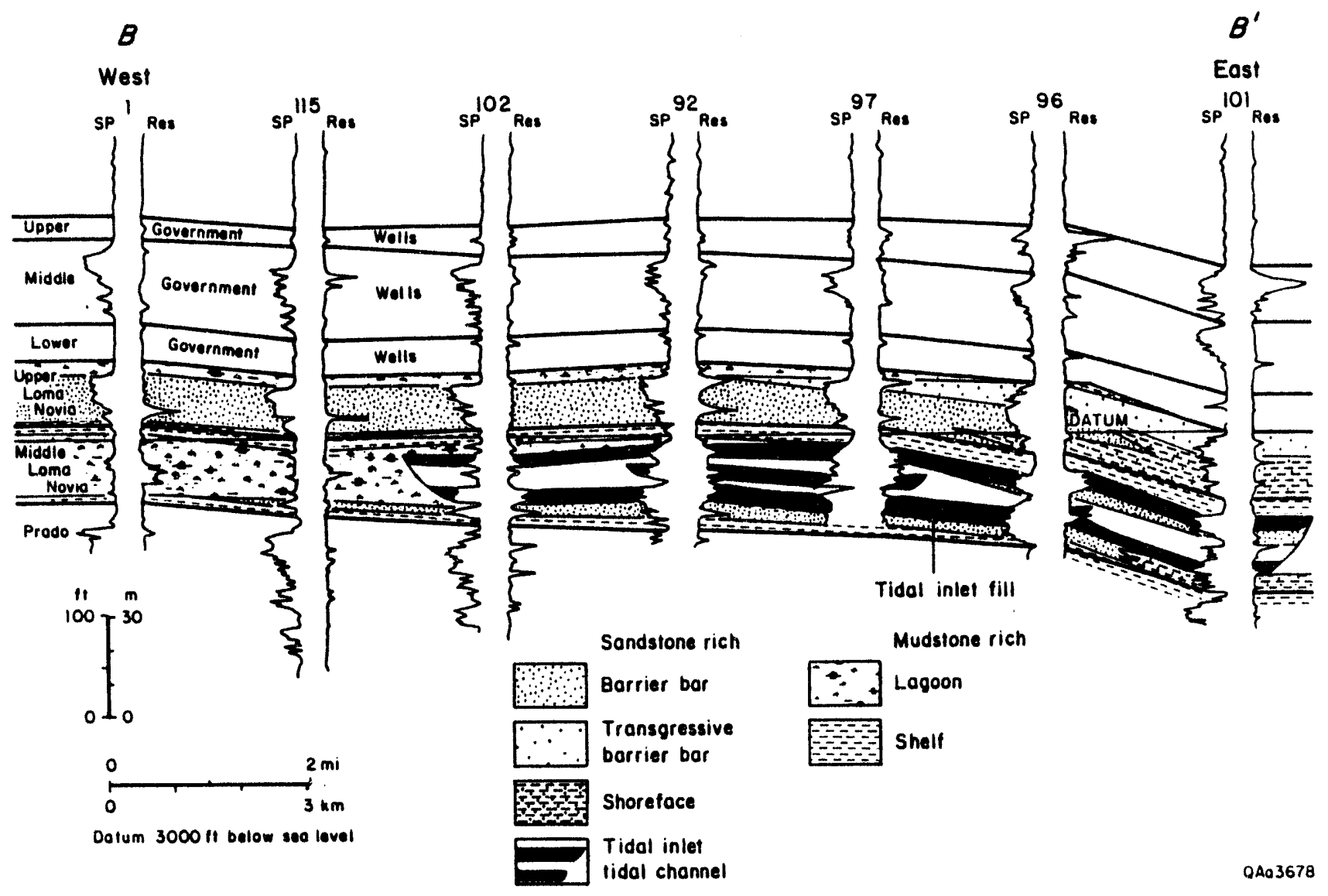

Figure 19. Structural cross section, Prado field, contrasting differing styles of sand-body architecture for barrier-bar facies in Upper Loma Novia reservoir sandstones and tidal-inlet fill in Middle Loma Novia reservoir sandstones. 
Tidal Channel-Inlet Fill Reservoir Model

The irregular thickness and distribution of Middle Loma Novia and Prado reservoir sandstones sharply contrast with the uniform thickness and percentage sandstone of the overlying Upper Loma Novia and Government Wells sandstones (fig. 19). The sandstone-rich facies of the Middle Loma Novia are characterized by abundant, upward-fining channel systems that are laterally discontinuous. In contrast, the overlying Upper Loma Novia contains little evidence of the cut-and-fill processes across the area of the barrier core. The tidal channels clearly pinch out both updip and downdip and thus are not a part of a fluvial-channel system (fig. 16). The facies of the Middle Loma Novia comprise a complex mosaic of environments as a result of variations in the depth and extent of tidal scour (fig. 18). In the southern part of Prado field, barrier-bar facies are preserved below the tidal inlet fill facies. In the central and northern part of the field, tidal cut and fill apparently scoured below the depth of the barrier bar.

The thickness of individual tidal channels ranged from $\mathbf{5}$ to $\mathbf{4 0} \mathrm{ft}$. Lateral connectivity of individual channels is difficult to identify unambiguously. Individual channels apparently are on the order of 500 to $1,000 \mathrm{ft}$ wide and extend updip less than $1 \mathrm{mi}$. The Middle Loma Novia contains at least three tidal channel/inlet fill sequences (fig. 19) that cut irregularly into upward-coarsening barrier-bar sandstones.

The lateral extent in a dip direction of sand-rich reservoir facies is narrower in the tidal channel-inlet fill model than in the overlying unsegmented barrier bar model. The thickness of individual tidal channels and the thickness of nests of tidal channels decreases toward the south. The direction of tidal channel migration is inferred to have been toward the south.

Sandstone and mudstone are intercalated within the tidal channel-inlet fill system. Although most channels are sandy, some channels are locally mud filled. Mudstone interbeds and numerous cut-and-fill structures combine to yield a complex facies mosaic that contains abundant permeability barriers and heterogeneities. The complex distribution of channel sandstones increases the probability that these facies heterogeneities could have formed favorable compartments that have been poorly drained of their original hydrocarbons to date. 


\section{DISCUSSION}

All sand bodies in the Prado field area display an updip and downdip termination, although the width of the belt across which sandstone is preserved varies from 5 to $15 \mathrm{mi}$. Similar assemblages of facies types also characterize each sandstone sequence. Facies mosaics can be complex within individual sand bodies. Fieldwide SP log facies mapping reveals the absence of fluvial facies characterized by dip-oriented upward-coarsening sandstone packages that connect with and supply sand to the shore-parallel sand bodies. This absence is interpreted to indicate the lack of major dip-oriented fluvial feeder systems. The distribution of seaward-stepping parasequence sets that make up the sand bodies of Prado field must have a primary source of strike-fed sediment predominantly from the north. Widespread subregional mapping has identified isolated upward-coarsening fluvial sand bodies associated with a possible unconformity far updip of the Prado field (fig. 7). A base-level lowering may have originally established the lower Jackson sandstones in the Prado field area by a forced regression from their former position $15 \mathrm{mi}$ updip.

Typically, there was little evidence from regional and fieldwide electric logs useful for distinguishing between lagoonal and shelf mudstone or for identifying an unconformity between the two facies. However, where present, lagoonal lignites characterized by low SP and high resistivity are useful indicators of lagoonal facies. Rare descriptive logs within Prado field have identified lignites overlying back-barrier sandstones. According to Kaiser (1974) and Kaiser and others (1980), such lagoonal lignites are common in the lower Jackson of South Texas and are developed near the tops of barrier/strandplain sandstones. The stratigraphic position of mudstones was used as a correlation guide, and low-resistivity zones within the mudstones provided useful correlation markers. Mudstones updip and behind the barrier/strandplain sandstones were interpreted to be predominantly lagoonal mudstones. For instance, thick progradational barrier-core sandstones are typically overlain by uniform, relatively thick mudstones. The basal portions of these mudstones probably represent lagoonal facies that continued the progradational pattern of the underlying sandstone sequence. The upper portion of the mudstones must represent shelf mudstones as a result of rapid relative sea-level rise in order for the overlying sandstone 
sequence to reinitiate a progradational parasequence set. The repetitive nature of stacked progradational parasequence sets indicates that shelf facies must underlie each parasequence set.

The two reservoir models identified at Prado field-unsegmented barrier bar and tidal inlet fillprovide useful criteria for identifying potential for reexploration for bypassed hydrocarbon-bearing compartments. The unsegmented barrier bar model is characterized by a uniform facies mosaic and by a general absence of internal heterogeneities that might provide barriers to hydrocarbon migration. In contrast, the tidal inlet fill model is characterized by abundant heterogeneities that could provide multiple opportunities for lateral and vertical barriers to hydrocarbon migration. The dip orientation of highly permeable tidal channels within the tidal inlet fill model also provides conduits for preferential channeling of water injected into the reservoir for pressure maintenance. Favorable sites for reexploration occur in the Middle Loma Novia where net- and percent-sandstone maps reveal updip-directed thick sandstones that may be related to tidal channel axes and resultant updip flood delta deposits. Such areas may have been incompletely drained as a result of lateral isolation from tidal scour or from mud drapes within tidal channels. Similarly, downdip sandstone thicks resulting from ebb deltas may be appropriate reservoirs; however, the low structural position of the ebb delta may cause the reservoir to be water wet.

\section{CONCLUSIONS}

1. Lower Jackson Group reservoirs have produced 23 million bbl and 32 million mcf gas from barrier-bar depositional systems at Prado field, Jim Hogg County, South Texas. An extensive pressure maintenance program during the 1970's failed to halt the steep decline in production. Fieldwide oil production declined to less than $5,000 \mathrm{bbl} / \mathrm{yr}$ in the late 1980 's. Recovery efficiency was 34 percent for oil and 69 percent for gas. The relatively low recovery efficiency has prompted efforts at field reexploration.

2. The four primary sand-body reservoirs at Prado field are Prado, Middle Loma Novia, Upper Loma Novia, and Upper Government Wells. The Upper Government Wells is the primary gas reservoir and the Middle Loma Novia is the primary oil reservoir. Sand-body architecture of individual reservoirs ranges from relatively simple to complex. Two reservoirs models describe the end-members of reservoir 
complexity at Prado field: (1) the tidal channel inlet fill model and (2) the unsegmented barrier-bar model. The older Prado and Middle Loma Novia sand bodies are complex arrangements sand-rich depositional environments including tidal channel inlet fill, barrier-bar core, back barrier, and shoreface. The tidal channel inlet fill reservoir model describes the primary reservoir environment of the Prado and Middle Loma Novia reservoirs. The younger Upper Loma Novia and Government Wells reservoirs sand bodies comprise a much simpler array of sand-rich depositional environments dominated by a prograrational and widespread barrier-bar core, back barrier, and shoreface. The unsegmented barrier-bar model describes the primary reservoir environment of the Upper Loma Novia and Middle Government Wells reservoirs.

3. Lower Jackson Group sandstones reflect an abrupt basinward shift in their initial shoreline position (Prado time) of approximately $15 \mathrm{mi}$ as a result of forced regression during relative base-level lowering. Subsequently oscillations of the shoreline resulted in the net progradation of $2 \mathrm{mi}$ of the shoreline through the Upper Government Wells.

4. Reexploration for additional hydrocarbon resources should concentrate in the complex and depositionally heterogeneous environments described in the tidal inlet fill reservoir model. Tidal channel environments comprise complex cut-and-fill processes associated with tidal inlet migration and ebb/flood delta deposition. Barrier core environments might retain untapped reservoir compartments lateral to mud-filled tidal inlet fills. The poor performance of the pressure maintenance program at Prado field underscores the critical importance of understanding reservoir heterogeneities prior to implementation of secondary or tertiary recovery operations.

\section{ACKNOWLEDGMENTS}

This work was supported by the U.S. Department of Energy and managed through Idaho National Engineering Laboratory Geopressured-Geothermal Program. The authors thank the following individuals and organizations for their assistance; Mark Miller, Petroleum Engineering Department, The University of Texas at Austin; Ray Fortuna, U.S. Department of Energy, Washington, D.C.; Mike Shook and 
Jane Negus-de Wys, Idaho National Engineering Laboratory; Charles Kimmell, Fanion Production Company; and Shell Exploration and Production Company. Technical editing was by Tucker F. Hentz. Drafting of the figures was supervised by Richard L. Dillon. Word processing was by Diane Ruetz, editing was by Amanda R. Masterson, and publication design was by Jamie H. Coggin. 


\section{REFERENCES}

Eargle, D. H., 1959, Stratigraphy of Jackson Group (Eocene), south-central Texas: American Association of Petroleum Geologists Bulletin, v. 43, no. 11, p. 2623-2635.

Fisher, W. L., and McGowen, J. H., 1969, Depositional systems in the Wilcox Group (Eocene) of Texas and their relationship to occurrence of oll and gas: American Association of Petroleum Geologists Bulletin, v. 53, no. 1, p. 30-54.

Fisher, W. L., Proctor, C. V., Jr., Galloway, W. E., and Nagle, J. S., 1970, Depositional systems in the Jackson Group of Texas-their relationship to oll, gas, and uranium: Gulf Coast Association of Geological Societies Transactions, v. 20, p. 234-261.

Galloway, W. E., 1989, Genetic stratigraphic sequences in basin analysis I: architecture and genesis of flooding-surface bounded depositional units: American Association of Petroleum Geologists Bulletin, v. 73, no. 2, p. 125-142.

Galloway, W. E., Hobday, D. K., and Magara, K., 1982, Frio Formation of the Texas Gulf Coast basin: depositional systems, structural framework, and hydrocarbon origin, migration, distribution, and exploration potential: The University of Texas at Austin, Bureau of Economic Geology Report of Investigations No. $122,78 \mathrm{p}$.

Galloway, W. E., Ewing, T. E., Garrett, C. M., Tyler, Noel, and Bebout, D. G., 1983, Atlas of major Texas oil reservoirs: The University of Texas at Austin, Bureau of Economic Geology Special Publication, $139 \mathrm{p}$.

Gai oway, W. E., Jirik, L. A., Morton, R. A., and DuBar, J. R., 1986, Lower Miocene (Fleming) depositional episode of the Texas coastal plain and continental shelf: structural framework, facies, and hydrocarbon resources: The University of Texas at Austin, Bureau of Economic Geology Report of Investigations No. 150, 50 p.

Galloway, W. E., and Cheng, E. S.-S., 1985, Reservoir facies architecture in a microtidal barrier systemFrio Formation, Texas Gulf Coast: The University of Texas at Austin, Bureau of Economic Geology Report of Investigations No. 144, $36 \mathrm{p}$.

Hamilton, D. S., in press, Potential for increased oil recovery from barrier/strandplain reservoirs of the Jackson-Yegua trend by geologically targeted infill drilling: examples from Seventy-Six West and Colmena-Cedro Hill fields, South Texas: The University of Texas at Austin, Bureau of Economic Geology Report of Investigations.

Hyatt, D. B., 1990, Geology and production characteristics of the Seventy-Six West field, Duval County, Texas: Gulf Coast Association of Geological Societies Transactions, v. 40, p. 305-318.

Kaiser, W. R., 1974, Texas lignite: near-surface and deep-basin resources: The University of Texas at Austin, Bureau of Economic Geology Report of Investigations No. 79, 70 p.

Kaiser, W. R., Ayers, W. B., Jr., and La Brie, L. W., 1980, Lignite resources in Texas: The University of Texas at Austin, Bureau of Economic Geology Report of Investigations No. 104, 52 p.

Krueger, W. C., Jr., 1968, Depositional environments of sandstones as interpreted from electrical measurements an introduction: Gulf Coast Association of Geological Societies Transactions, v. 18, p. 226-241. 
Murray, G. E., and Wilbert, L. J., Jr., 1950, Jacksonian stage: American Association of Petroleum Geologist Bulletin, v. 34, no. 10, p. 1990-1997.

Ramos, A., and Galloway, W. E., 1990, Facies and sand-body geometry of the Queen City (Eocene) tidedominated delta-margin embayment, NW Gulf of Mexico basin: Sedimentology, v. 37, p. 1079-1098.

Schultz, A. L., 1986, Geology of the first Mirando Sand, South Lopez Unit, Lopez field, Webb and Duval Counties, Texas, in Stapp, W. L., ed., Contributions to the geology of South Texas: San Antonio, South Texas Geological Society, p. 100-108.

Sellards, E. H., Adkins, W. S., and Plummer, F. B., 1932, The geology of Texas: volume 1: stratigraphy: The University of Texas at Austin, Bureau of Economic Geology Publication 3232, 1007 p.

Seni, S. J., and Walter, T., in press, Geothermal and heavy-oil resources in Texas with emphasis on direct use of geothermal fluid for enhanced recovery of heavy oil: The University of Texas at Austin, Bureau of Economic Geology Geological Circular.

Tyler, Noel, and Ambrose, W. A., 1985, Facies architecture and production characteristics of strandplain reservoirs in the Frio Formation, Texas: The University of Texas at Austin, Bureau of Economic Geology Report of Investigations No. 146, 42 p.

1986, Depositional systems and oil and gas plays in the Cretaceous Olmos Formation, South Texas: The University of Texas at Austin, Bureau of Economic Geology Report of Investigations No. 152,42 p.

Tyler, Noel, Gholston, J. C., and Ambrose, W. A., 1986, Genetic stratigraphy and oil recovery in an upper Cretaceous wave-dominated deltaic reservoir, Big Wells (San Miguel) field, South Texas: The University of Texas at Austin, Bureau of Economic Geology Report of Investigations No. $153,38 \mathrm{p}$.

West, T. S., Jr., 1963, Typical stratigraphic traps, Jackson trend of South Texas: Gulf Coast Association of Geological Societies Transactions, v. 13, p. 67-78. 
Appendix 1. Well $\log$ list.

\begin{tabular}{|c|c|c|}
\hline ID & Company & Lease and Number \\
\hline$\infty$ & Gorman, Glerhart and Howe & S. K. East No. 4 \\
\hline 002 & Gorman, Glerhart and Howe & S. K. East No. 40 \\
\hline 000 & Gorman, Glerhart and Howe & S. K. East No. 1 \\
\hline 004 & Gorman, Gierhart and Howe & S. K. East No. 14 \\
\hline 005 & Gorman, Gierhart and Howe & S. K. East No. 5 \\
\hline 006 & Gorman, Glerhart and Howe & S. K. East No. 3 \\
\hline 007 & Gorman, Glerhart and Howe & S. K. East No. 2 \\
\hline 008 & Sun Oll Co. & S. K. East No. 1-C \\
\hline 009 & F.P.Schwab et al. & J.H. Allen No. 2 \\
\hline 010 & La Gloria Co. & S. K. East No. 1 \\
\hline 011 & La Gloria Co. & S. K. East No. 2 \\
\hline 012 & Prado Oil and Gas Co. & S. K. East No. 311 \\
\hline 013 & Gorman, Gierhart and Howe & S. K. East No. B-2 \\
\hline 014 & Gorman, Gierhart and Howe & S. K. East No. E-3 \\
\hline 015 & Prado Oll and Gas Co. & S. K. East No. 164 \\
\hline 016 & Sun Oll Co. & S. K. East No. 3 \\
\hline 017 & Blair-Vreeland & J.H. Allen No. 1 \\
\hline 018 & La Gloria Co. & S. K. East No. 3 \\
\hline 019 & Prado Oil and Gas Co. & S. K. East No. 301 \\
\hline 020 & Gorman, Gierha rt and Howe & S. K. East No. E-1 \\
\hline 021 & Prado Oil and Gas Co. & S. K. East No. 55 \\
\hline 022 & Prado Oll and Gas Co. & S. K. East No. 66 \\
\hline 023 & Prado Oll and Gas Co. & S. K. East No. 78 \\
\hline 024 & Sohio Petroleum Co. & S. K. East No. 429 \\
\hline 025 & Gorman, Gierhart and Howe & S. K. East No. C-1 \\
\hline 040 & Joseph S. Morris et al. & Mestena No. 2 \\
\hline 041 & Joseph S. Morris et al. & Mestena No. 3 \\
\hline 042 & Joseph S. Morris et al. & Mestern No. 4 \\
\hline 043 & Joseph S. Morris et al. & Mestena No. 5 \\
\hline 044 & CPC Exploration & Mestena No. 2 \\
\hline 045 & Joseph S. Morris et al. & Mestena No. 7 \\
\hline 046 & Joseph S. Morris et al. & Mestera No. 6 \\
\hline 047 & H. M. Howell & Mestena No. 1 \\
\hline 048 & Joseph S. Morris et al. & Mestera No. 1 \\
\hline 049 & Jake L. Hamon & Reynaldo Saenz GUNo. 1 \\
\hline 050 & Carter Exploration Co. & Reynaldo Saenz No. 1 \\
\hline 051 & CPC Exploration & Mestena No. 1 \\
\hline 052 & Humble Oil and Refining & Mrs. A. K. East No. 1 \\
\hline 053 & Stroube Prod.-Hill Prod. & Mestena No. 1 \\
\hline 054 & Humble Oil and Refining & Mrs. A. K. East No. 3 \\
\hline 055 & Humble OIl and Refining & Mrs. A. K. East No. 2 \\
\hline 056 & Alta Vista Exploration Inc. & Loma No. 1 \\
\hline 057 & Humble & Canales No. 1 \\
\hline 058 & Patrick Petroleum Co. & Frankie Armstrong No. 1 \\
\hline 059 & Topp Petroleum Co. & Canales Heirs No. 1 \\
\hline 060 & Prado Oll and Gas Co. & S. K. East No. 93 \\
\hline 061 & Prado Oil and Gas Co. & S. K. East No. 95 \\
\hline 062 & Gorman, Gierhart and Howe & S. K. East No. 7 \\
\hline
\end{tabular}


Appendix 1 (cont)

\begin{tabular}{|c|c|c|}
\hline ID & Company & Lease and Number \\
\hline 063 & Gorman, Gierhart and Howe & S. K. East No. 6 \\
\hline 064 & Gorman, Gierhart and Howe & S. K. East No. 8 \\
\hline 065 & Gorman, Gierhart and Howe & S. K. East No. 10 \\
\hline 066 & Gorman, Gierhart and Howe & S. K. East No. 11 \\
\hline 067 & Gorman, Gierhart and Howe & S. K. East No. 12 \\
\hline 068 & Gorman, Gierhart and Howe & S. K. East No. 13 \\
\hline 069 & Prado Oll and Gas Co. & S. K. East No. 59 \\
\hline 070 & Prado Oil and Gas Co. & S. K. East No. 60 \\
\hline 071 & Prado Oll and Gas Co. & S. K. East No. 68 \\
\hline 072 & Prado Oil and Gas Co. & S. K. East No. 71 \\
\hline 073 & Prado Oil and Gas Co. & S. K. East No. 72 \\
\hline 074 & Standard Oil Prod. Co. & S. K. East No. A-501 \\
\hline 075 & Prado Oil and Gas Co. & S. K. East No. 70 \\
\hline 076 & Prado Oil and Gas Co. & S. K. East No. 69 \\
\hline 077 & Gorman, Gierhart and Howe & S. K. East No. 9 \\
\hline 078 & Sun Oil Co. & S. K. East No. 4 \\
\hline 079 & Alta Vista Exploration Co. & Arroya-Baluarte No. 1 \\
\hline 080 & Miller Bros. \& Bowling & J.M. Tygart No. 1 \\
\hline 081 & The Texas Co. & E. L. Armstrong No. 1 \\
\hline 090 & Gorman, Geirhart and Howe & S. K. East No. 16 \\
\hline 091 & Gorman, Gierhart and Howe & S. K. East No. 19 \\
\hline 092 & Gorman, Gierhart and Howe & S. K. East No. 20 \\
\hline 093 & Gorman, Gierhart and Howe & S. K. East No. 24 \\
\hline 094 & Corman, Gierhart and Howe & S. K. East No. 25 \\
\hline 095 & Gorman, Gierhart and Howe & S. K. East No. 26 \\
\hline 096 & Gorman, Gierhart and Howe & S. K. East No. 27 \\
\hline 097 & Gorman, Gierhart and Howe & S. K. East No. 29 \\
\hline 098 & Gorman, Gierhart and Howe & S. K. East No. 36 \\
\hline 099 & Gorman, Gierhart and Howe & S. K. East No. 52 \\
\hline 100 & Gorman, Gierhart and Howe & S. K. East No. 53 \\
\hline 101 & Gorman, Gierhart and Howe & S. K. East No. 54 \\
\hline 102 & Gorman, Gierhart and Howe & S. K. East No. 67 \\
\hline 103 & Gorman, Gierhart and Howe & S. K. East No. 74 \\
\hline 104 & Gorman, Gierhart and Howe & S. K. East No. 75 \\
\hline 105 & Gorman, Gierhart and Howe & S. K. East No. 77 \\
\hline 106 & Gorman, Gierhart and Howe & S. K. East No. 89 \\
\hline 107 & Gorman, Gierhart and Howe & S. K. East No. 91 \\
\hline 108 & Gorman, Gierhart and Howe & S. K. East No. 208 \\
\hline 109 & Gorman, Gierhart and Howe & S. K. East No. 225 \\
\hline 110 & Sohio Petroleum Co. & S. K. East No. 315 \\
\hline 111 & Prado Oil and Gas Co. & S. K. East No. 76 \\
\hline 112 & Gorman, Gierhart and Howe & S. K. East No. 21 \\
\hline 113 & Gorman, Gierhart and Howe & S. K. East No. 22 \\
\hline 114 & Prado Oil and Gas Co. & S. K. East No. 79-A \\
\hline 115 & Prado Oil and Gas Co. & S. K. East No. 90 \\
\hline 116 & Prado Oil and Gas Co. & S. K. East No. 78 \\
\hline 117 & L. H. Haring Jr. & Well Brothers A-1 \\
\hline 118 & Philip L. Davidson & Well Brothers No. 1 \\
\hline
\end{tabular}


Appendix 1 (cont.)

\begin{tabular}{|c|c|c|}
\hline ID & Company & Lease and Number \\
\hline 119 & M. L. Massingill et al. & Howel McCampbell No. 1 \\
\hline 120 & Gorman, Gierhart and Howe & S. K. East No. 15 \\
\hline 121 & Gorman, Gierhart and Howe & S. K. East No. 23 \\
\hline 122 & Gorman, Gierhart and Howe & S. K. East No. 30 \\
\hline 123 & Gorman, Glerhart and Howe & S. K. East No. 33 \\
\hline 124 & Gorman, Gierhart and Howe & S. K. East No. 34 \\
\hline 125 & Gorman, Gierhart and Howe & S. K. East No. 35 \\
\hline 126 & Gorman, Gierhart and Howe & S. K. East No. 37 \\
\hline 127 & Gorman, Gierhart and Howe & S. K. Fast No. 38 \\
\hline 128 & Gorman, Gierhart and Howe & S. K. East No. 41 \\
\hline 129 & Gorman, Gierhart and Howe & S. K. East No. 42 \\
\hline 130 & Gorman, Glerhart and Howe & S. K. East No. 43 \\
\hline 131 & Gorman, Gierhart and Howe & S. K. East No. 44 \\
\hline 132 & Gorman, Gierhart and Howe & S. K. East No. 45 \\
\hline 133 & Gorman, Gierhart and Howe & S. K. East No. 46 \\
\hline 134 & Gorman, Gierhart and Howe & S. K. East No. 47 \\
\hline 135 & Gorman, Gierhart and Howe & S. K. East No. 48 \\
\hline 136 & Gorman, Gierhart and Howe & S. K. East No. 49 \\
\hline 137 & Gorman, Gierhart and Howe & S. K. East No. 50 \\
\hline 138 & Gorman, Gierhart and Howe & S. K. East No. 51 \\
\hline 139 & Prado Oil and Gas Co. & S. K. East No. 56 \\
\hline 140 & Prado Oil and Gas Co. & S. K. East No. 58 \\
\hline 141 & Prado Oil and Gas Co. & S. K. East No. 61 \\
\hline 142 & Prado Oil and Gas Co. & S. K. East No. 62 \\
\hline 143 & Prado Oil and Gas Co. & S. K. East No. 63 \\
\hline 144 & Prado Oil and Gas Co. & S. K. East No. 64 \\
\hline 145 & Prado Oil and Gas Co. & S. K. East No. 65 \\
\hline 146 & Prado Oil and Gas Co. & S. K. East No. 73 \\
\hline 147 & Prado Oil and Gas Co. & S. K. East No. 80 \\
\hline 148 & Prado Oil and Gas Co. & S. K. East No. 82 \\
\hline 149 & Prado Oil and Gas Co. & S. K. East No. 83 \\
\hline 150 & Prado Oil and Gas Co. & S. K. East No. 84 \\
\hline 151 & Prado Oil and Gas Co. & S. K. East No. 85 \\
\hline 152 & Prado Oil and Gas Co. & S. K. East No. 86 \\
\hline 153 & Prado Oil and Gas Co. & S. K. East No. 87 \\
\hline 154 & Prado Oil and Gas Co. & S. K. East No. 88 \\
\hline 155 & Prado Oil and Gas Co. & S. K. East No. 224 \\
\hline 156 & Prado Oil and Gas Co. & S. K. East No. 81 \\
\hline 157 & Gorman, Gierhart and Howe & S. K. East No. 18 \\
\hline 158 & Gorman, Gierhart and Howe & S. K. East No. 31 \\
\hline 159 & Gorman, Gierhart and Howe & S. K. East No. 17 \\
\hline 160 & Gorman, Gierhart and Howe & S. K. East No. 32 \\
\hline 161 & Prado Oil and Gas Co. & S. K. East No. 98 \\
\hline 162 & Gorman, Gierhart and Howe & S. K. East No. 39 \\
\hline 163 & Prado Oil and Gas Co. & S. K. East No. 99 \\
\hline 164 & Prado Oil and Gas Co. & S. K. East No. 96 \\
\hline 165 & Prado Oil and Gas Co. & S. K. East No. 97 \\
\hline 166 & Sun Oil Co. & Well Brothers No. 43 \\
\hline
\end{tabular}


Appendix 1 (cont.)

\begin{tabular}{|c|c|c|}
\hline ID & Company & Lease and Number \\
\hline 167 & L. H. Haring Jr. & Mestena No. 1 \\
\hline 168 & Killam \& Hurd & Well et al. No. 1 \\
\hline 169 & Sun Oil Co. & Mestena No. 2 \\
\hline 170 & South Texas Oll \& Gas Co. & McCampbell No. 1 \\
\hline 171 & Main Oil Co. & McCampbell No. 1 \\
\hline 172 & Sun Oil Co. & Well Bros. No. 2 \\
\hline 173 & Sun Oil Co. & Well Bros. No. 3 \\
\hline 174 & Dyco Petroleum Co. & D. F. McCampbell No. 1 \\
\hline 175 & Humble Oil \& Refining Co. & Mestena Oil \& Gas No. 3-H \\
\hline 176 & Humble Oil \& Refining Co. & Mestena Oil \& Gas No. 3-B \\
\hline 177 & Clavo \& Hamill & Mestena Oil \& Gas No. 1-B \\
\hline 180 & Gorman, Gierhart and Howe & S. K. East No. 104 \\
\hline 181 & Gorman, Gierhart and Howe & S. K. East No. 105 \\
\hline 182 & Gorman, Gierhart and Howe & S. K. East No. 106 \\
\hline 183 & Gorman, Gierhart and Howe & S. K. East No. 107 \\
\hline 184 & Gorman, Gierhart and Howe & S. K. East No. 108 \\
\hline 185 & Gorman, Gierhart and Howe & S. K. East No. 115 \\
\hline 186 & Gorman, Gierhart and Howe & S. K. East No. 116 \\
\hline 187 & Gorman, Gierhart and Howe & S. K. East No. 120 \\
\hline 188 & Gorman, Gierhart and Howe & S. K. East No. 123 \\
\hline 189 & Prado Oil and Gas Co. & S. K. East No. 126 \\
\hline 190 & Prado Oil and Gas Co. & S. K. East No. 127 \\
\hline 191 & Prado Oil and Gas Co. & S. K. East No. 128 \\
\hline 192 & Prado Oll and Gas Co. & S. K. East No. 133 \\
\hline 193 & Prado Oil and Gas Co. & S. K. East No. 138 \\
\hline 194 & Prado Oil and Gas Co. & S. K. East No. 139 \\
\hline 195 & Prado Oil and Gas Co. & S. K. East No. 140 \\
\hline 196 & Prado Oil and Gas Co. & S. K. East No. 141 \\
\hline 197 & Prado Oil and Gas Co. & S. K. East No. 142 \\
\hline 198 & Prado Oil and Gas Co. & S. K. East No. 143 \\
\hline 199 & Prado Oil and Gas Co. & S. K. East No. 144 \\
\hline 200 & Prado Oil and Gas Co. & S. K. East No. 145 \\
\hline 201 & Prado Oil and Gas Co. & S. K. East No. 146 \\
\hline 202 & Prado Oil and Gas Co. & S. K. East No. 147 \\
\hline 203 & Prado Oil and Gas Co. & S. K. East No. 149 \\
\hline 204 & Prado Oil and Gas Co. & S. K. East No. 153 \\
\hline 205 & Prado Oil and Gas Co. & S. K. East No. 184 \\
\hline 206 & Prado Oil and Gas Co. & S. K. East No. 186 \\
\hline $20 \%$ & Prado Oil and Gas C.). & S. K. East No. 187 \\
\hline 208 & Prado Oil and Gas Co. & S. K. East No. 188 \\
\hline 209 & Prado Oil and Gas Co. & S. K. East No. 191 \\
\hline 210 & Prado Oil and Gas Co. & S. K. East No. 192 \\
\hline 211 & PI Energy & Kennedy Foundation No. 1-B \\
\hline 230 & Gorman, Gierhart and Howe & S. K. East No. 109 \\
\hline 231 & Gorman, Gierhart and Howe & S. K. East No. 122 \\
\hline 232 & Gorman, Gierhart and Howe & S. K. East No. 124 \\
\hline 233 & Prado Oil and Gas Co. & S. K. East No. 134 \\
\hline 234 & Prado Oil and Gas Co. & S. K. East No. 135 \\
\hline
\end{tabular}


Appendix 1 (cont.)

\begin{tabular}{|c|c|c|}
\hline ID & Company & Lease and Number \\
\hline 235 & Prado Oil and Gas Co. & S. K. East No. 136 \\
\hline 236 & Prado Oil and Gas Co. & S. K. East No. 137 \\
\hline 237 & Prado Oil and Gas Co. & S. K. East No. 150 \\
\hline 238 & Prado Oil and Gas Co. & S. K. East No. 151 \\
\hline 239 & Prado Oil and Gas Co. & S. K. East No. 152 \\
\hline 240 & Prado Oil and Gas Co. & S. K. East No. 156 \\
\hline 241 & Prado Oil and Gas Co. & S. K. East No. 157 \\
\hline 242 & Prado Oil and Gas Co. & S. K. East No. 158 \\
\hline 243 & Prado Oil and Gas Co. & S. K. East No. 163 \\
\hline 244 & Prado Oil and Gas Co. & S. K. East No. 189 \\
\hline 245 & Prado Oil and Gas Co. & S. K. East No. 190 \\
\hline 246 & Gorman, Gierhart and Howe & S. K. East No. 202 \\
\hline 247 & Gorman, Gierhart and Howe & S. K. East No. 203 \\
\hline 248 & Gorman, Gierhart and Howe & S. K. East No. 204 \\
\hline 249 & Gorman, Gierhart and Howe & S. K. East No. 207 \\
\hline 250 & Prado Oil and Gas Co. & S. K. East No. 209 \\
\hline 251 & Prado Oil and Gas Co. & S. K. East No. 221 \\
\hline 252 & Sohio Petroleum Co. & S. K. East No. 226 \\
\hline 253 & Sohio Petroleum Co. & S. K. East No. 227 \\
\hline 254 & Prado Oil and Gas Co. & S. K. East No. 194 \\
\hline 255 & Prado Oil and Gas Co. & S. K. East No. 119 \\
\hline 256 & Prado Oil and Gas Co. & S. K. East No. 110 \\
\hline 257 & Prado Oil and Gas Co. & S. K. East No. 298 \\
\hline 258 & Prado Oil and Gas Co. & S. K. East No. 214 \\
\hline 259 & Prado Oil and Gas Co. & S. K. East No. 195 \\
\hline 270 & Gorman, Gierhart and Howe & S. K. East No. 111 \\
\hline 271 & Gorman, Gierhart and Howe & S. K. East No. 112 \\
\hline 272 & Prado Oil and Gas Co. & S. K. East No. 148 \\
\hline 273 & Prado Oil and Gas Co. & S. K. East No. 154 \\
\hline 274 & Prado Oil and Gas Co. & S. K. East No. 155 \\
\hline 275 & Prado Oil and Gas Co. & S. K. East No. 160 \\
\hline 276 & Prado Oil and Gas Co. & S. K. East No. 161 \\
\hline 277 & Prado Oil and Gas Co. & S. K. East No. 162 \\
\hline 278 & Prado Oil and Gas Co. & S. K. East No. 165 \\
\hline 279 & Prado Oil and Gas Co. & S. K. East No. 166 \\
\hline 280 & Prado Oil and Gas Co. & S. K. East No. 168 \\
\hline 281 & Prado Oil and Gas Co. & S. K. East No. 169 \\
\hline 282 & \begin{tabular}{|l} 
Prado Oil and Gas Co. \\
\end{tabular} & S. K. East No. 170 \\
\hline 283 & Prado Oil and Gas Co. & S. K. East No. 172 \\
\hline 284 & Prado Oil and Gas Co. & S. K. East No. 175 \\
\hline 285 & Prado Oil and Gas Co. & S. K. East No. 176 \\
\hline 286 & Prado Oil and Gas Co. & S. K. East No. 179 \\
\hline 287 & Prado Oil and Gas Co. & S. K. East No. 211 \\
\hline 288 & Prado Oil and Gas Co. & S. K. East No. 212 \\
\hline 289 & Prado Oil and Gas Co. & S. K. East No. 215 \\
\hline 290 & Prado Oil and Gas Co. & S. K. East No. 216 \\
\hline 291 & Prado Oil and Gas Co. & S. K. East No. 219 \\
\hline 292 & Prado Oil and Gas Co. & S. K. East No. 213 \\
\hline
\end{tabular}


Appendix 1 (cont.)

\begin{tabular}{|l|l|l|}
\hline ID & \multicolumn{1}{|c|}{ Company } & \multicolumn{1}{|c|}{ Lease and Number } \\
\hline 293 & Prado Oil and Gas Co. & S. K. East No. 222 \\
\hline 294 & Hughes Texas Petroleum Co. & S. K. East No. C-1 \\
\hline 295 & Prado Oil and Gas Co. & S. K. East No. 199 \\
\hline 296 & Prado Oil and Gas Co. & S. K. East No. 174 \\
\hline 297 & Prado Oil and Gas Co. & S. K. East No. 173 \\
\hline 298 & Prado Oil and Gas Co. & S. K. East No. 171 \\
\hline 299 & Prado Oil and Gas Co. & S. K. East No. 159 \\
\hline 300 & Prado Oil and Gas Co. & S. K. East No. 184 \\
\hline 301 & Prado Oil and Gas Co. & S. K. East No. 223 \\
\hline 302 & Gorman, Gierhart and Howe & S. K. East No. B-17 \\
\hline 303 & Gorman, Gierhart and Howe & S. K. East No. B-1 \\
\hline 304 & Prado Oil and Gas Co. & S. K. East No. 178 \\
\hline 305 & Prado Oil and Gas Co. & S. K. East No. 177 \\
\hline 306 & Prado Oil and Gas Co. & S. K. East No. 181 \\
\hline 307 & Prado Oil and Gas Co. & S. K. East No. 180 \\
\hline 308 & Prado Oil and Gas Co. & S. K. East No. 299 \\
\hline 309 & Prado Oil and Gas Co. & S. K. East No. 217 \\
\hline 310 & Prado Oil and Gas Co. & S. K. East No. 218 \\
\hline 311 & Prado Oil and Gas Co. & S. K. East No. 167 \\
\hline 312 & Prado Oil and Gas Co. & S. K. East No. 113 \\
\hline 313 & D. A. Hughes Co. & S. K. East No. D-3 \\
\hline 314 & Hughes Texas Petroleum & East No. 8/6/86 \\
\hline 315 & Gifford Oil Co. & D. O. Gallaghar No. 1-B \\
\hline & & \\
\hline
\end{tabular}


Appendix 2. Cross section well list.

A - $\mathbf{A}^{\prime}$

\begin{tabular}{|r|r|l|l|}
\hline No. & BEG No. & \multicolumn{1}{|c|}{ Operator } & \multicolumn{1}{|c|}{ Fee } \\
\hline 1 & 37 & Shell Oil Co. & No. 1 Bruni \& Killam Trust \\
\hline 2 & 36 & Superior Oil Co. & No. 1 Marie MoGrath \\
\hline 3 & 130 & Hughes \& Hughes & No. 1 "G" L. A. Hinnant \\
\hline 4 & 2 & Atlantic Refining & No. A-1 Stroman-Armstrong \\
\hline 5 & 8 & Jake L. Hamon & No. 1 Reuben Holbein \\
\hline 6 & 10 & Standard Oil Co. & No. 2 Reuben Holbein \\
\hline 7 & 14 & Jake L. Hamon & No. 2 Francisco Perez \\
\hline 8 & 33 & C\& K Petroleum & No. 1 Martinez \\
\hline 9 & 34 & Edwin L. Cox \& Berry R. Cox & No. 1 A. A. Martinez \\
\hline 10 & 307 & Amerada Petroleum Co. & No. 2 A. A. Martinez \\
\hline 11 & 313 & W. Earl Rowe & No. 1 Martinez \\
\hline 12 & 59 & Topp Petroleum Co. & No. 1 Canales Heirs \\
\hline 13 & 23 & Prado Oil \& Gas Co. & No. 78 S. K. East \\
\hline 14 & 246 & Gorman, Gierhart \& Howe & No. 202 S. K. East \\
\hline 15 & 108 & Prado Oil \& Gas Co. & No. 208 S. K. East \\
\hline 16 & 168 & Killiam \& Hurd Ltd. & No. 1 Ruth Well et al. \\
\hline 17 & 167 & Haring & No. 1 Mestena \\
\hline
\end{tabular}

B - B'

\begin{tabular}{|r|r|l|l|}
\hline No. & BEG No. & \multicolumn{1}{|c|}{ Operator } & \multicolumn{1}{|c|}{ Fee } \\
\hline 4 & 1 & Prado Oil \& Gas Co. & No.4 S. K. East \\
\hline 90 & 115 & Prado Oil \& Gas Co. & No.90 S. K. East \\
\hline 67 & 102 & Prado Oil \& Gas Co. & No.67 S. K. East \\
\hline 20 & 92 & Prado Oil \& Gas Co. & No. 20 S. K. East \\
\hline 29 & 97 & Prado Oil \& Gas Co. & No.29 S. K. East \\
\hline 27 & 96 & Prado Oil \& Gas Co. & No. 27 S. K. East \\
\hline 54 & 101 & Prado Oil \& Gas Co. & No.54 S. K. East \\
\hline
\end{tabular}


C- $C^{\prime}$

\begin{tabular}{|c|c|c|c|}
\hline No. & BEG No. & Operator & Fee \\
\hline 1 & 285 & Prado Oil \& Gas Co. & No. 176 S. K. East \\
\hline 2 & 286 & Prado Oil \& Gas Co. & No. 179 S. K. East \\
\hline 3 & 275 & Prado Oil \& Gas Co. & No. 160S. K. East \\
\hline 4 & 272 & Prado Oil \& Gas Co. & No. 148 S. K. East \\
\hline 5 & 186 & Gorman, Gierhart \& Howe & No. B-16 S. K. East \\
\hline 6 & 192 & Prado Oil \& Gas Co. & No. 133 S. K. East \\
\hline 7 & 208 & Prado Oll \& Gas Co. & No. 188S. K. East \\
\hline 8 & 195 & Prado Oil \& Gas Co. & No. 140 S. K. East \\
\hline 9 & 244 & Prado Oil \& Gas Co. & No. 189 S. K. East \\
\hline 10 & 127 & Gorman, Gierhart \& Howe & No. 38 S. K. East \\
\hline 11 & 139 & Prado Oil \& Gas Co. & No. 56 S. K. East \\
\hline 12 & 131 & Gorman, Gierhart \& Howe & No. 44 S. K. East \\
\hline 13 & 129 & Gorman, Gierhart \& Howe & No. 42 S. K. East \\
\hline 14 & 128 & Gorman, Gierhart \& Howe & No. 41 S. K. East \\
\hline 15 & 122 & Gorman, Gierhart \& Howe & No. 30 S. K. East \\
\hline 16 & 121 & Gorman, Gierhart \& Howe & No. 23S. K. East \\
\hline 17 & 95 & Gorman, Gierhart \& Howe & No. 26 S. K. East \\
\hline 18 & 104 & Prado Oil \& Gas Co. & No. 75 S. K. East \\
\hline 19 & 102 & Prado Oil \& Gas Co. & No. 67 S. K. East \\
\hline 20 & 107 & Prado Oil \& Gas Co. & No. 91 S. K. East \\
\hline 21 & 98 & Gorman, Gierhart \& Howe & No. 36 S. K. East \\
\hline 22 & 21 & Prado Oil \& Gas Co. & No. 55 S. K. East \\
\hline
\end{tabular}

$D-D$

\begin{tabular}{|r|r|l|l|}
\hline No. & BEG No. & \multicolumn{1}{|c|}{ Operator } & \multicolumn{1}{|c|}{ Fee } \\
\hline 1 & 60 & Prado Oil \& Gas Co. & No. 93 S. K. East \\
\hline 2 & 65 & Gorman, Gierhart \& Howe & No. 10 S. K. East \\
\hline 3 & 68 & Gorman, Gierhart \& Howe & No. 13 S. K. East \\
\hline 4 & 72 & Prado Oil \& Gas Co. & No. 71 S. K. East \\
\hline 5 & 69 & Prado Oil \& Gas Co. & No.59 S. K. East \\
\hline 6 & 147 & Prado Oil \& Gas Co. & No. 80 S. K. East \\
\hline 7 & 127 & Gorman, Gierhart \& Howe & No. 38 S. K. East \\
\hline 8 & 156 & Prado Oil \& Gas Co. & No. 81 S. K. East \\
\hline 9 & 126 & Gorman, Gierhart \& Howe & No. 37 S. K. East \\
\hline 10 & 148 & Prado Oil \& Gas Co. & No. 82 S. K. East \\
\hline 11 & 125 & Gorman, Gierhart \& Howe & No. 35 S. K. East \\
\hline 12 & 161 & Prado Oil \& Gas Co. & No. 98 S. K. East \\
\hline 13 & 253 & Sohio Petroleum Co. & No. 227 S. K. East \\
\hline 14 & 257 & Prado Oil \& Gas Co. & No. 298 S. K. East \\
\hline 15 & 251 & Prado Oil \& Gas Co. & No. 221 S. K. East \\
\hline
\end{tabular}



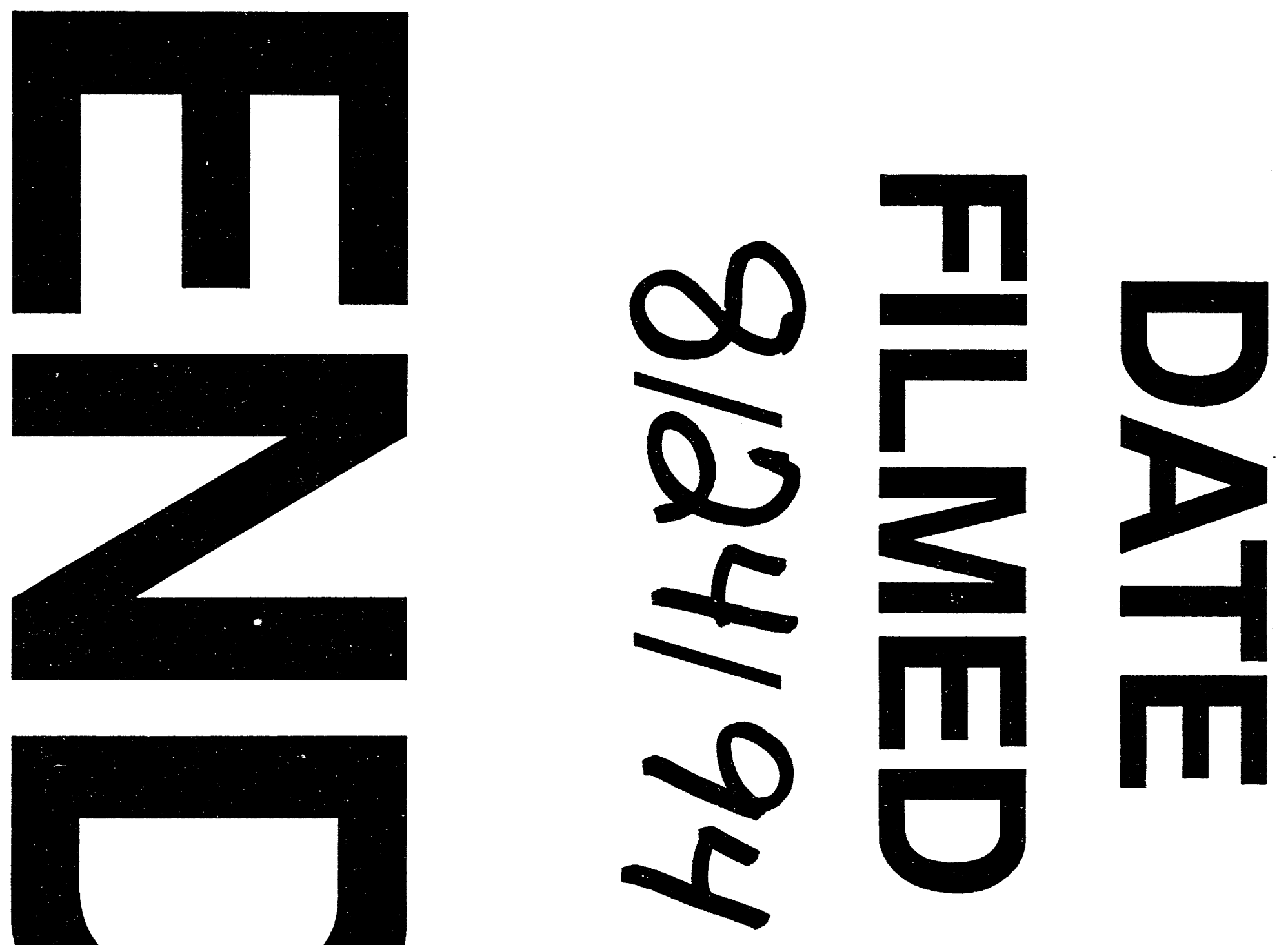
